\title{
JOAQUÍN SENDEROS Y YEMEYÁ, DOS PROTAGONISTAS "SUBALTERNOS" EN LA NOVELA ECLIPSE DE LUNA, DE RICARDO ESTUPIÑÁN BRAVO
}

\author{
Alexis Francisco Uscátegui Narváez \\ Universidad Mariana \\ Grupo de Investigación "FORMA". Formación de maestros \\ auscategui@umariana.edu.co
}

\begin{abstract}
RESUMEN
Este artículo sintetiza los resultados de un trabajo investigativo que busca, a través de la crítica literaria y la teoría de la subalternidad, repensar la historia de aquellas personas a las que se consideraba como subalternos en la sociedad latinoamericana. Este documento destaca los aportes socioculturales de dos razas (indígena y afrodescendiente), representadas por dos protagonistas de la novela Eclipse de luna, del escritor colombiano Ricardo Estupiñán Bravo, quienes por cosas del destino afrontan un apasionante universo de amor, dolor y muerte. En términos claves, erguido con firmeza sobre dichos supuestos, Estupiñán expresa, con esta maravillosa novela, la dolorosa y cruda verdad de la subalternidad en Nariño, el desarraigo y la miseria de Cumbal y Barbacoas. Por esta razón, se realizó una interpretación que desplaza los discursos coloniales al olvido y legitima la heterogeneidad cultural y literaria que presentan las letras de Nariño, el mundo sureño, en cuyo verbo prolifera la libertad.
\end{abstract}

Palabras clave: Subalternidad, Eclipse de luna, Subalternos, Yemeyá,Joaquín Senderos. 


\title{
JOAQUÍN SENDEROS AND YEMEYÁ, TWO SUBORDINATE MAIN CHARACTERS IN THE NOVEL MOON ECLIPSE BY RICARDO ESTUPIÑÁN BRAVO
}

\begin{abstract}
This article summarizes the results of a research project which seeks, through literary criticism and the theory of subalternity, to rethink the history of those who are regarded as subordinate in Latin American society. This paper highlights the social and cultural contributions of two races (indigenous and African descent), represented by two main characters in the novel entitled Lunar Eclipse by the Colombian writer Ricardo Estupiñán Bravo. These characters, for reasons of fate face an exciting universe of love, pain and death. In key terms, standing firmly on these assumptions, Estupiñán through this wonderful novel describes the painful and raw truth of subalternity in Nariño and the uprooting and misery of Cumbal and Barbacoas. For this reason, an interpretation that displaces colonial discourses to forgetfulness and legitimizes the cultural and literary heterogeneity expressed in the letters of Nariño - the southern world-, was performed-, in which the word freedom revolves.
\end{abstract}

Key words: Subalternity, Moon Eclipse, Subaltern, Yemeyá, Joaquín Senderos.

\section{JOAQUÍN SENDEROS E YEMEYÁ, DOIS PROTAGONISTAS SUBORDINADOS" NA NOVELA ECLIPSE DE LUNA, DE RICARDO ESTUPIÑÁN BRAVO}

\begin{abstract}
RESUMO
Este artigo sintetiza os resultados de un trabalho de pesquisa que busca, através da crítica literaria e da teoría da subordinação, repensar a historia daquelas pessoas às quais são considerada como subordinados da sociedade latinoamericana. Este documento destaca as contribuições sociais e culturais de duas raças (indígena e afrodescendente), representadas por dois protagonistas da novela Eclipse de luna, do escritor colômbiano Ricardo Estupiñán Bravo, quem por coisas do destino diante de um apaixonante universo de amor, dor e morte. Em termos chaves, erguer-se firmemente sobre ditas suposições, Estupiñán expressa, com esta maravilhosa novela, a dolorosa e crua verdade da subordinação em Nariño, o desenraizamento e miséria de Cumbal e Barbacoas. Por esta razão, se realizou uma interpretação que move os discursos coloniais ao esquecimento e legitima a heterogeneidade cultural e literária que apresentam as letras de Nariño, o mundo do sul, no qual se dá a proliferação da liberdade.
\end{abstract}

Palavras chaves: Subodinação, Eclipse de luna, Subordinado, Yemeyá, Joaquín Senderos. 


\section{INTRODUCCIÓN}

Las teorías poscoloniales y decoloniales han dejado una huella inquebrantable con respecto a la legitimación y liberación del Otro (el negro, el homosexual, el indio, la mujer, el anciano, el pobre, el mendigo, entre otros) ante el eurocentrismo y el anglocentrismo, con el propósito de ubicar a estas personas en un componente sociocultural digno, porque cada uno de ellos aporta al bienestar y desarrollo de un determinado Estado. Al enfocar una relectura crítica de la sociedad latinoamericana, se puede encontrar que se ha liberado al subalterno de manera física, mas no de pensamiento; es decir, la colonialidad, si se entiende que el término es totalmente diferente al colonialismo, aún no termina. Como dijo Dussel, en su seminario "Filosofía Política en América Latina Hoy", en el programa de Doctorado en Estudios Culturales Latinoamericanos de la Universidad Andina Simón Bolívar, la colonialidad dio luz a los europeos y oscuridad a las periferias, lo que las ha dejado en lo más oscuro del Renacimiento. Si se discurre lo socio-ideológico y se retoman las perspectivas del ser oprimido, se permitirá crear un sendero a la realidad que merece vivir el subalterno. Cada territorio latinoamericano tiene múltiples características literarias y culturales; dicho de otra manera, los laberintos literarios se entrecruzan entre valores heterogéneos que no sólo se manifiestan en lo erudito, sino también en lo popular y aborigen ${ }^{\mathbf{1}}$.

Cándido sostiene que el arte es un sistema simbólico de comunicación interhumana y que todo proceso de comunicación presupone un comunicante, en este caso el artista; un comunicado, o sea la obra; un comunicativo, que es el público al que se dirige; todo este proceso lleva a una interpretación por medio de una previa recepción ${ }^{2}$. Así, el propósito fundamental de esta investigación fue realizar una interpretación crítica de la novela Eclipse de luna, del escritor nariñense Ricardo Estupiñán Bravo ${ }^{3}$, a partir de la Teoría de la Subalternidad. El Proyecto, al inscribirse en la Línea de Investigación Crítica Literaria Latinoamericana y Etnoliteratura, del programa de Maestría en Etnoliteratura de la Universidad de Nariño, cumple un menester centralizado en discernir los aspectos subalternos de la obra a través de un proceso hermenéutico, dado que el documento men-

1 José Cornejo. La formación de la tradición literaria en el Perú (Lima: Centro de estudios y publicaciones, 1989), 186-188.

2. Antonio Cándido. Literatura y sociedad (México: Universidad Nacional Autónoma de México, 2007) 186-188.

3. Ricardo Estupiñán Bravo nació en Cumbal en 1959. Estudió Administración Agropecuaria en la Universidad de la Salle en Bogotá; es abogado de la Universidad de Nariño; Especialista en Derecho Financiero de la Universidad del Rosario. Dirigió el M-19 en Nariño; ha sido, también, Asesor de Cabildos indígenas, de alcaldías y de la Asamblea Departamental de Nariño. Dentro de su creación literaria, ha publicado los libros: La tierra de los Cumbales (2002), Caminando por el sur (2003) y la novela Eclipse de luna (2011). 
cionado no puede entenderse como un simple argumento literario, pues fue necesario reflexionar sobre sus entresijos narrativos para destacar múltiples elementos relevantes, entre ellos el rol que cumplen los personajes "subalternos" en la sociedad latinoamericana.

En estas condiciones, la novela Eclipse de luna es una narración que contempla distintos parajes significativos de acuerdo con su temática central: la subalternidad; no obstante, al analizar rigurosamente su contenido, se pueden destacar otros aspectos, como el amor, el dolor y la muerte; muchos se preguntarán por qué retomar procesos minoritarios en la actualidad, si la colonia ya "terminó" hace mucho tiempo. La respuesta es trágica, al encontrar, aún en las sociedades latinoamericanas, mandatos hegemónicos que no subordinan -tal vez- físicamente a sus servidores, pero sí de forma conceptual, ideológica, religiosa, etc. Existen casos en que a los indios y afrodescendientes no se los tiene en cuenta para la construcción de un Estado. Joaquín Senderos, uno de los protagonistas de la novela, por ejemplo, es un campesino de procedencia indígena del municipio de Cumbal, ubicado al sur del Departamento de Nariño, asentado precisamente junto al gran Macizo colombiano, una región fría, con una temperatura de nueve grados centígrados, donde trabaja arduamente como hielero para garantizar un mejor porvenir a su familia. El Nevado de Cumbal es un cerro, considerado por Guerrero "como un gigante de la cordillera de los Andes; alcanza 4890 metros sobre el nivel del mar; de sus entrañas se extrae, para uso doméstico, el azufre $y$, para un pequeño comercio interregional, el hielo"4 .

Yemeyá es la protagonista, que también lucha día a día para obtener algunas pepitas de oro en su tierra natal, llamada Barbacoas. Esta municipalidad de Nariño, en palabras de Guerra:

Se encuentra incrustada en la zona verde montañosa, en las estribaciones de la Cordillera occidental de los Andes, con unos 28 grados de temperatura. Los ríos que rodean la región son limpios y guardan en su lecho invaluables cantidades de oro de finísimo quilate; entre sus ríos más afluentes está el Telembí ${ }^{5}$.

La raza de Yemeyá contempla un gran ramillete historial en el mundo, pues su descendencia proviene del África, un continente que ha estado en constante lucha por su revaloración cultural y social, para romper los paradigmas racistas impuestos por las ideologías tradicionales del neo-colonialismo. Esta barbacoana, sin duda alguna, ostenta la riqueza ancestral africana, de un etnos lleno de cos-

4. Gerardo Guerrero. Estudios sobre el municipio de Cumbal (Bogotá: Internacional de Impresos el Dorado, 1998), 23.

5. Gonzalo Guerra. Tierra del oro: Reseña histórica de Barbacoas (Pasto: Imprenta Departamental, 1980), 8. 
tumbres, tradiciones, mitos y leyendas, que se ven explícitos en varios capítulos de Eclipse de luna. A la raza negra se la ha opacado conceptualmente; sin embargo, han existido, en la historia, intelectuales que han luchado por la dignidad de los afro, como José Martí y Nelson Mandela; en términos de Oswald de Andrade, fueron unos antropófagos de los pensamientos occidentales, que han liderado procesos de lucha universal para liberar a los oprimidos, a los subalternos que vivieron como esclavos durante muchos años y han enriquecido a la industria burguesa ${ }^{6}$. Andrade también sustenta que la antropofagia une socialmente a los individuos cuando se eliminan de raíz los regímenes de autoridad occidental, porque es un tabú que se debe convertir en tótem; se deben devorar sus "valores" europeos y las sublimaciones antagónicas. Traídos en las carabelas, antes de que los españoles colonizaran América, sus pobladores ya habían descubierto la libertad. La explotación colonial se extendió también por Nariño, donde poblaciones como Barbacoas padecieron de muchos abusos; por eso esta novela revela los hábitos impuestos por los colonos: minería, agricultura, construcción, servicio doméstico, entre otros, oficios únicos que realizaron sus habitantes debido a la desigualdad social, lo que generó también una estigmatización por siglos, en busca de la inferioridad y el genocidio de la raza negra y también indígena. Fanon expresa que la opresión colonial persiste en la actualidad; está inmersa en cualquier proceso sociocultural de las naciones; dicho dominio es simplificador, desintegra la existencia de las culturas de ley tribal, niega al afro y al indígena como miembro de un grupo social, rechaza sus costumbres e imaginarios, trata de obliterar su estructura biológica, porque lo blanco es lo predominante ${ }^{7}$; por ello es necesario escribir una nueva historia.

Los postulados sobre los estudios culturales, poscoloniales y decoloniales de Moraña (2003), Castro (1998), Mignolo (2000) y Dussel (2013), entre otros, también han facilitado el análisis de los aspectos subalternos de la novela Eclipse de luna, ya que, a partir de sus planteamientos, se comprendió cuáles son los fundamentos teóricos que respaldan los discursos subalternos inmersos en su contenido literario. Por otra parte, la investigación se orientó a través de la Teoría Estética de la Recepción de Jauss (1986), que facilitó, desde su paradigma, la producción de un nuevo texto, resultado de una interpretación de la obra objeto en estudio. En la actualidad, la narrativa ofrece al lector, de una forma implícita o explícita, múltiples horizontes, que pueden percibirse por los sentidos; cada vez que se relee una obra, se pueden encontrar más significados, que enriquecen el argumento central y transportan al intérprete a explorar nuevos conocimientos. Esta postura se relaciona con los planteamientos de Jauss cuando sugiere que la relación entre lector y texto juega un rol relevante dentro del análisis de una obra

6. Oswald de Andrade. Oswald de Andrade: obra escogida (Caracas: Biblioteca de Ayacucho, 1981), 70.

7. Franz Fanon. Los condenados de la tierra (México: Fondo de Cultura Económica, 1981), 192. 
literaria, pues las dos partes tienen que diferenciarse, organizarse e interpretarse como dos horizontes diferentes: el literario interno, implicado por la obra, y el horizonte del entorno, aportado por el lector de una sociedad determinada ${ }^{8}, \mathrm{y}$ todo ello para reconocer cómo la expectativa y la experiencia se enlazan entre sí y, por tanto, se produce un momento de nueva significación, en discrepancia con el análisis literario usual, que sólo permite obtener el significado superficial de la obra, porque no facilita una exploración más exhaustiva del caso, lo que ocasiona que el receptor se conformase con lo que el texto informa explícitamente.

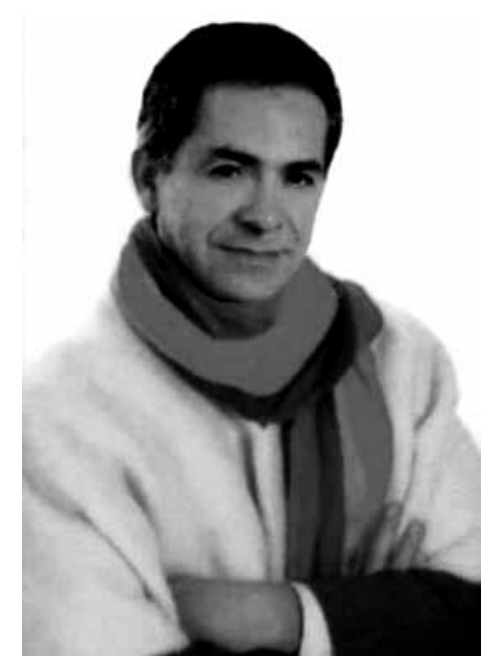

Escritor: Ricardo Estupiñán Bravo

Fuente: Archivo personal Ricardo Estupiñán.

La novela Eclipse de luna, de Ricardo Estupiñán Bravo, muestra un contenido significante para los estudios poscoloniales, entre ellos la subalternidad, puesto que, en su perspectiva conceptual, legitima los valores culturales que el subalterno tiene dentro de un grupo social. La novela entre manos registra los principios de vida del indio (Cumbal) y el afrodescendiente (Barbacoas) del Departamento de Nariño. Por ello, se realizó una aserción crítica literaria basada en la teoría de la subalternidad sobre dicha novela, en la cual se ha postulado una concepción interpretativa sobre el papel pluricultural que cumplen estos personajes dentro del panorama social y literario latinoamericano.

En suma, la carencia de crítica literaria en Nariño ha generado que el conglomerado literario en el Departamento poco se reconozca a nivel nacional y

8. Hans Jauss. Experiencia estética y hermenéutica literaria (Madrid: Taurus, 1986), 17. 
latinoamericano. Las producciones literarias requieren de un mayor estudio interpretativo; es decir, se debe realizar un trabajo literario más exhaustivo con el propósito de que las mismas publicaciones existan universalmente; no atañe si el autor no es consagrado, lo relevante es posibilitar el conocimiento sobre el valor que aporta dicho contenido a la disertación sobre las letras tal y como lo han manifestado nuestros coterráneos Alberto Quijano Guerrero, Cecilia Caicedo Jurado, Jorge Verdugo Ponce, Edgar Bastidas Urresty, Javier Rodrizales, sobre el estudio de las letras en el sur-occidente colombiano.

\section{ASPECTOS METODOLÓGICOS}

De acuerdo con los diversos tipos de investigación que existen dentro del campo de las Ciencias humanas, este trabajo se orientó en la investigación documental y bibliográfica y la hermenéutica, por cuanto permitió al investigador escudriñar los senderos inconclusos, indescifrables e inexplorados en los ámbitos narrativos de la obra narrativa Eclipse de luna. La investigación es un camino complejo, que el investigador debe transitar, pero también sentir lo indagado, debe dejar huellas significativas que aporten a una favorable solución del problema. Por ello, al analizar e interpretar el contenido que ofrece la novela en cuestión, el hermeneuta debe desentrañar los mundos y sentidos existentes en el argumento central de la narración, porque dicho mundo necesita ser valorado por el lector. Por esta razón, este tipo de investigación estableció una fuente interpretativa que revalora el papel social, cultural y literario que cumplen los subalternos en la novela ya mencionada. Descolonizar, de una u otra forma, los discursos hegemónicos existentes en la obra literaria objeto de estudio, para abrir el camino de los grupos humanos (indio y afro) hacia las redes interculturales de la humanidad.

Por lo anterior, y con el respaldo teórico y conceptual de la investigación, se generó un campo de análisis e interpretación sobre los sujetos que se consideran como subalternos dentro del lenguaje hegemónico implícito en la novela Eclipse de luna. También se efectuó, a través de un marco hermenéutico, puesto que permitió desentrañar un determinado contexto cultural del subalterno inmerso en la novela Eclipse de luna. Esta tipología investigativa permitió, en cierto modo, explorar la relación ideológica sujeta a los estudios de la subalternidad; de esta manera, se requiere una idónea interpretación de la obra objeto de estudio. No es lo mismo decir que se entiende un texto, que interpretarlo, pues, al decir entender se está haciendo referencia a que se puede dar razón sobre lo que trata el texto (literal), es hacer un diagnóstico o descripción de lo que se leyó; en cambio, si se interpreta, se está originando un camino para llegar al sentido adecuado del texto, ya sea en el discurso oral o escrito. 
Así mismo, la hermenéutica se cataloga como un recurso investigativo que permite buscar la verdad, lo incomprensible y lo oculto. Es una metodología que le permite al sujeto indagar o comprender ciertos menesteres científicos que posibilita cada ciencia humana, en relación con la interpretación y los reconocimientos de múltiples realidades; el que interpreta trasforma la sociedad, porque en el mundo existe una infinidad de conocimientos que están esperando ser descubiertos.

En esta perspectiva, se efectuó un trabajo hermenéutico, acompañado de la Teoría Estética de la Recepción de Hans Robert Jauss, puesto que permitió ir más allá del simple hecho de describir o analizar literalmente la novela Eclipse de luna; permitió interpretar el argumento subalterno y el sentido literario que ella contempla; de igual forma, facilitó dar a conocer una perspectiva crítica frente a la posición de los subalternos presentes en la obra literaria objeto de estudio. El método estético de recepción de Jauss ha reconocido múltiples lecturas sobre la novela Eclipse de luna; cada persona, cada comunidad, cada geografía latinoamericana (lectores o receptores), podrán leer de una forma nueva dicho texto literario y encontrar múltiples significados o sentidos, desde su horizonte de expectativa. De este modo, no se trata de recurrir a la hermenéutica como acto de entender y explicar algo inconcluso, sino de optar por un hacer más interpretativo que solucione las dudas literarias de la novela, a través de una recepción que va más allá de la intención del autor, para darle un mejor reconocimiento a la misma obra. En cualquier obra literaria, se pueden encontrar acontecimientos sociales y culturales en el contexto de cómo fue escrito dicho texto. Jauss señala un orden interpretativo idóneo en el acto estético de la recepción:

La hermenéutica literaria tiene la doble tarea de diferenciar metódicamente las dos formas de recepción: es decir, la de aclarar, por un lado, el proceso actual, en el que el efecto y la significación del texto se concretizan para el lector del presente, y la de reconstruir, por otro, el proceso histórico, en el que los lectores de épocas distintas han recibido e interpretado el texto siempre de modo diferente ${ }^{9}$.

Es así como, en la novela Eclipse de luna, se optó por recurrir a este método literario, puesto que, a través de la lectura interpretativa, el lector o receptor, en la obra, podrá analizar, interpretar, construir, re-crear, re-escribir, reconstruir y crear un nuevo texto, que será parte de la consolidación de un trabajo crítico literario. Por ejemplo, la siguiente figura representa el horizonte de expectativa que surge por medio de la recepción literaria en esta novela:

9. Jauss, Experiencia estética y hermenéutica literaria, 14. 


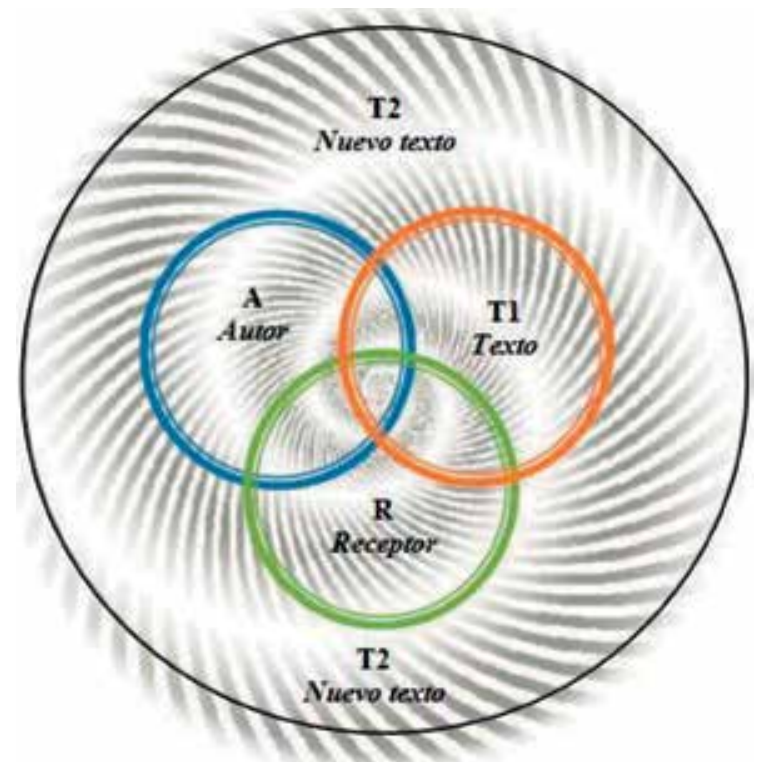

\section{Aplicación del “Método Estético de la Recepción” en la novela Eclipse de luna.}

Fuente: esta investigación.

A = Autor, Ricardo Estupiñán Bravo.

$\mathbf{T 1}=$ Texto, novela Eclipse de luna.

$\mathbf{R}=$ Receptor, investigador.

T2 = Nuevo texto, es el resultado que realizó el receptor a partir de la lectura interpretativa de la novela objeto de estudio.

El esquema anterior es la secuencia teórico-práctica que se efectuó para la estructuración del análisis e interpretación de la novela Eclipse de luna a través de este método. Según Jauss, la relación entre lector y texto juega un rol importante dentro del análisis de una obra literaria, pues las dos partes tienen que diferenciarse, organizarse e interpretarse como dos horizontes diferentes: el literario interno, implicado por la obra, y el del entorno, aportado por el lector de una sociedad determinada, y todo ello para reconocer cómo la expectativa y la experiencia se enlazan entre sí y, por tanto, se produce un momento de nueva significación ${ }^{\mathbf{1 0}}$.

Esto va en discrepancia con el análisis literario tradicional, que sólo permite obtener a grandes rasgos el significado central del contenido de la obra literaria, no facilita una exploración más exhaustiva del caso, lo que ocasiona

10. Jauss, Experiencia estética y hermenéutica literaria, 17. 
que el receptor se conforme con simples conjeturas sobre lo que se informa explícitamente en el texto: autor, obra, género literario, contexto, personajes, argumento y auditorio.

\section{ESTADO DEL ASUNTO Y RESULTADOS}

Si la crítica es el ejercicio del criterio, su función tiene que estar estrechamente relacionada con este hecho: la crítica literaria emite un juicio sobre la obra literaria. Por supuesto, así como un rey no es sólo corona, la crítica no es sólo juicio: el juicio ordena, gobierna, pero a su vez necesita estar sustentado en labores sin las cuales él mismo no se justificaría (...) En este sentido, la fuerza de una crítica literaria latinoamericana se pone de manifiesto al ser capaz no sólo de enjuiciar nuestras cosas, sino también las cosas del resto del mundo ${ }^{11}$.

Por lo anterior y para consolidar el proceso investigativo en la novela objeto de estudio, se planteó la siguiente pregunta guía: ¿Cómo interpretar la novela Eclipse de luna, de Ricardo Estupiñán Bravo, a través de los fundamentos de la teoría de la subalternidad?

Ahora bien, con base en distintas teorías, se construyó un marco conceptual que permitió el análisis e interpretación de la novela Eclipse de luna, con postulados que tienen en cuenta los procesos pluri-étnicos de los "subalternos". Este es un marco que dinamiza la labor individual y social de los grupos minoritarios en cuestión y proyecta la legitimación del otro, que critica las hegemonías y busca la transformación de la realidad social. De este modo, la siguiente sección expone los diferentes fundamentos que respaldaron el tema objeto de estudio.

La subalternidad es una de las teorías postcoloniales más significativas dentro de la historia sociocultural y literaria, ya que manifiesta diversos aspectos que revaloran los discursos que se han considerado como de las minorías. El historiador indio Ranajit Guha ha reformulado la historiografía de los pueblos colonizados excluidos por el discurso eurocentrista, para devolverles, así, su valor social. Los estudios sobre la subalternidad tienen sus orígenes a finales del siglo XX en la India, lo que ha utilizado Guha para referirse a los discursos hegemónicos que dominan sobre los subalternos (movimientos de insurgencia campesina); más adelante, el mismo autor, en su libro Las voces de la historia y otros estudios subalternos, atribuye este término para dar el carácter general de subordinación en la sociedad del sureste asiático, donde el autor expone potencialmente sus ideas renovadoras, que registran las voces subalternas silenciadas por la historia oficial. Con respecto a la subalternidad en Latinoamérica, existe el

11. Roberto Fernández. Para una teoría de la literatura hispanoamericana (Bogotá: Instituto Caro y Cuervo, 1995), 137-38. 
Grupo de Estudios Subalternos, que se ha encargado de estudiar cómo confluyen las diferentes circunstancias históricas y cómo se requiere buscar nuevas formas de pensar y de actuar políticamente en Latinoamérica.

Desde esta perspectiva, al escudriñar el contenido literario de Eclipse de luna, se puede hallar una mutua relación de los estudios subalternos con el eje central que constituye el argumento de la novela, porque los dos personajes principales de la obra se estigmatizan como "minorías", puesto que sus trabajos y formas de vida los enmarcan dentro de ese procedimiento subalternizante ${ }^{12}$. No obstante, Joaquín, un campesino, descendiente indígena del municipio de Cumbal, y Yemeyá, una afrodescendiente de la municipalidad de Barbacoas, cumplen otro tipo de funciones, dignas de valorarse en los procesos culturales y sociales del país y Latinoamérica. La subalternidad, según Moraña, en su investigación sobre "El boom subalterno", "es un fenómeno de diseminación ideológica de una categoría englobante y homogeneizadora por la que se intenta abarcar a todos aquellos sectores subordinados ante los discursos y praxis del poder"13; y aclara lo siguiente en relación con el vocablo subalterno:

El término aparece incluido para hacer referencia a los desposeídos y marginalizados por el régimen colonial, pero la connotación denigratoria del término impide utilizarlo como interpelación de los vastos sectores a los cuales debe abarcar el utopismo de la emancipación. En las teorizaciones actuales, el concepto de subalternidad se vuelve a potenciar a partir de la elaboración gramsciana, en la cual el marxista italiano hace referencia a los estratos populares que, ante la unidad histórica de las clases dirigentes, se hacen presentes a través de una activación episódica, presentándose como un nivel disgregado y discontinuo con grados variables y negociados de adhesión a los discursos y praxis hegemónicos ${ }^{14}$.

A través de esta aclaración, que Moraña sustenta, se puede decir que los regímenes coloniales y poscoloniales han sido una "vanguardia" ideológica de poder que jerarquizó de manera minoritaria los discursos subalternos, para impedir que emanciparan sus concepciones y pensamientos ideológicos propios; esto significa que dichos sistemas pretendieron homogeneizar una ideología que unificara el movimiento y los propósitos que estos sistemas sostienen.

En Eclipse de luna están inmersos algunos de estos aspectos; por ejemplo, al revisar minuciosamente varios capítulos de la novela, se puede encontrar que hubo explotación a los habitantes de Barbacoas con respecto a la extracción de oro; la novela objeto de estudio se re-crea en una posición geográfica donde la

12. Este término se refiere al proceso en el que a un grupo humano (considerado como minoría) lo domina conceptualmente un régimen hegemónico.

13. Mabel Moraña. El Boom del Subalterno (México: Castro \& Mendieta Editores, 1998), http://www. ensayistas.org/critica/teoria/castro/Mabel.htm (6 de febrero de 2013).

14. Moraña. El Boom del Subalterno, 16. 
raza negroide revela siglos de historia en relación con la subalternidad. Después de la llegada de los españoles a esta tierra, las comunidades afro de este municipio comenzaron a padecer de muchas vulneraciones; a pesar de que tenían todo el oro a su disposición, las explotaron en diversos trabajos. Estupiñán manifiesta: "Barbacoas ha sido la despensa aurífera de América. Desde mil quinientos cincuenta y seis, cientos de libras de oro se enviaron a la monarquía ibérica"15 y España.

En esta medida, Estupiñán expresa que los esclavos de Barbacoas recibían su respectivo pago sólo si llenaban una totuma de oro cada día; esto fue irónico, ya que esta tierra del oro y la libertad sobrevivió encadenada a la miseria, en condiciones precarias. De este modo, se podría afirmar que estuvieron presentes las hegemonías (los españoles), que subalternizaron a los indios ${ }^{\mathbf{1 6}}$ y negros, los esclavizaron con la explotación del mineral dorado. Por eso, los subalternos (afrodescendientes, indios, negros, campesinos, mujeres, entre otros) han promovido un movimiento categórico migrante, que se expandió por la sociedad en busca de sus propios ideales, al realizar una revolución ideológica que consagrara sus propias facultades físicas y mentales dentro de la sociedad; se podría denominar, como hipótesis de esta causa, un "boom del subalterno", que Moraña reconoce:

El Boom hace alusión al montaje ideológico-conceptual que promueve la subalternidad como parte de una agenda exterior, vinculada a un mercado donde aquella noción se afirma como un valor de uso e intercambio ideológico y como marca de un producto que se incorpora, a través de diversas estrategias de promoción y reproducción ideológica, al consumo cultural globalizado. En un segundo nivel, la expresión se refiere al modo en que las relaciones de subordinación (explotación, sujeción, marginación, dependencia) político-social, se transforman en campo de conocimiento, o sea se re-producen como objeto de interpretación y espacio de poder representacional $^{17}$.

Desde este punto de vista, el sujeto subalternizado se ha liberado de las opresiones ideológicas, que el poder colonizador impuso; ahora, su principal propósito es buscar sus formas independientes de vivir y pensar dentro de una sociedad sumamente heterogénea, multiculturalista, pluriétnica. Para retomar un episodio de la novela Eclipse de luna, está el enamoramiento de Joaquín con Yemeyá; a pesar de provenir de dos razas diferentes, unen su sangre por medio de un eclipse metafórico, fruto del amor y pasión en tierras nariñenses.

15. Ricardo Estupiñán, Eclipse de luna (Pasto: Edinar, 2011), 59.

16. Se hace referencia a los indios, porque en Barbacoas habitaron distintas comunidades indígenas, como los Sindaguas, Telembíes, Barbacoas, Iscuandés y Tapajes.

17. Moraña, El Boom del Subalterno, 7. 
La noción de subalternidad ha tomado relevancia, algunas décadas atrás, cuando el paradigma de la ideología hegemónica (sistemas dominantes) se ha debilitado debido a los cambios sociales establecidos en la sociedad. Por esta razón, surgió el trabajo del Grupo de Estudios Subalternos, una organización interdisciplinaria de intelectuales sud-asiáticos dirigida por Ranajit Guha, quien inició un proyecto dedicado al estudio del subalterno en América Latina. Este grupo de intelectuales ha buscado establecer, a través de sus indagaciones, la resignificación de los factores vivenciales de los subalternos dentro de distintas colectividades en Latinoamérica. Dichas investigaciones se han efectuado, según meticulosos análisis, en las epistemologías realizadas en las Ciencias sociales y humanas, en las distintas políticas sociales de poder que han mantenido sus argumentos falaces. El grupo ha discutido los discursos que las élites coloniales y poscoloniales manejan dentro de lo que implicaría hablar de prácticas hegemónicas respecto a los subalternos. En los avances de estas investigaciones, se ha podido determinar que los dependientes realizaron una insurrección frente a los grupos dominantes, al sostener, en sus elocuencias, que no son una comunidad que debe ser subordinada como minoritaria dentro de los procesos sociales y culturales de una nación.

De lo anterior se puede registrar que Joaquín, al igual que sus padres y hermanos, conforma una familia que lucha día a día por sobrevivir ante las inestables condiciones de pobreza y el insoportable frío que despliega el clima de su región, Cumbal. Joaquín ama a su tierra, sus coterráneos, trabaja por su familia como extractor de hielo del cerro nevado, una osadía de diez arduas horas de trabajo que termina en las horas de la tarde, al cargar el hielo sobre su espalda, hielo que vende a Misia Blanca, una vendedora de chupones y helados de paila en la plaza de esta municipalidad, quien le suministra una irrisoria suma de dinero que apenas le alcanza para comprar algunos productos y alimentos para el sustento diario.

Comprender e interpretar una novela no es tarea fácil; se requiere de un juicioso encuentro entre el lector y la obra, una lectura que no se estanque en lo superficial o literal, sino que sea íntima, apasionante, que permita descubrir el mundo multicultural en cada relectura. El Departamento de Nariño presenta más de un siglo de producción literaria, pues desde que se publicó, en 1894, la primera novela, La expiación de una madre, de José Rafael Sañudo, los escritores de la región se preguntaron, tal vez, por qué no se conocen sus obras a nivel nacional e internacional, y es que todo se debe a que el territorio aún carece de crítica literaria, puesto que no ha existido un medio disertador que se encargue de comentar, reseñar y divulgar los contenidos literarios que se publican en el Departamento. A pesar de que algunos investigadores han reconocido, dentro de sus estudios críticos, a diversos escritores nariñenses, este menester todavía no 
satisface la difusión que merecen dichos textos; aunque varios sean de carácter costumbrista y sólo muestren un reflejo de su época, merecen ser estudiados.

Rincón señala que la crítica literaria latinoamericana inició un nuevo sendero a partir de 1950, debido a que no se podían seguir evaluando las obras literarias por medio de teorías coloniales que opacaban el valor racial del continente americano. A través del tiempo, los procesos sociales cambian y con ellos la literatura; es decir, con los años, los escritores escriben a partir de nuevas posturas socioculturales que les permiten comunicar un sentido actual del medio en que se vive, lo cual significa que su comprensión pasa, obviamente, por la consideración de las nuevas mediaciones existentes entre los procesos sociales de producción y recepción literarias; Rincón sostiene que los métodos críticos han cambiado, lo que volvería absurdo analizar e interpretar la nueva producción literaria sin excluir los dominios eurocentristas ${ }^{\mathbf{1 8}}$.

El corpus literario en Nariño manifiesta una gran particularidad heterogénea, con diversos valores culturales, dignos de ser estudiados en diferentes campos, entre ellos la crítica literaria. Cada obra publicada en la región presenta múltiples temáticas y expresiones, que se analizan superficialmente; en consecuencia, las historias de las regiones, en general, se han constituido en uno de los medios de difusión de sus valores diferenciadores, con el objeto de legitimar autores y obras jamás mencionadas en las grandes historias de la literatura nacional.

Eclipse de luna es una obra narrativa publicada en cinco ediciones por el escritor nariñense Ricardo Estupiñán Bravo. Dentro de su estructura, la novela tiene diez capítulos; es una narración intradiagética, donde su argumento vislumbra una gran riqueza lexicográfica, representada en quechuismos; su terminología y valor semántico representan el acervo lingüístico de dos dialectos de Nariño, lugar en el cual se desarrolla la historia: Cumbal y Barbacoas.

Para Bajtín, la novela "es una forma puramente compositiva de organización de las masas verbales. A través de ella se realiza, en el objeto estético, la forma arquitectónica de acabamiento artístico de un acontecimiento histórico o social, constituyendo una variante de culminación ética"19, por la que comunica y trasfiere, por medio de su contenido literario, una axiología sujeta a temas o a un argumento central. Asimismo, Bajtín considera que la novela, como todo, "es un fenómeno pluriestilístico, plurilingüe y plurivocal. El investigador se encuentra en ella con unidades estilísticas heterogéneas, que algunas veces se hallan situadas en diferentes planos lingüísticos, y que están sometidas a diferentes normas estilísticas"20.

18. Carlos Rincón. El cambio en la noción de literatura (Bogotá: Instituto Colombiano de Cultura, 1978$), 141$. 19. Mijaíl Bajtín, Teoría y estética de la novela (Madrid: Taurus, 1989), 25.

20. Bajtín, Teoría y estética de la novela, 80. 
De este modo, Estupiñán recupera el espacio vivencial de los grupos subalternos dentro del marco social en Nariño; su novela, por su contenido pluriétnico y su nivel de simbolismo, requiere varias lecturas para comprender su verdadero sentido, lo que hace que, hasta el momento, no exista una reflexión, un análisis, reseña o ensayo que supla las exigencias que presenta la obra con respecto al tema de los subalternos (indio, negro). Frente a sus planteamientos estructurales, la obra narrativa tiene una tradicional secuencia lineal (inicio, nudo y desenlace) que conduce al lector a entretejer un argumento de amor, sufrimiento y muerte; sin embargo, en cada entresijo se halla la in-dignidad de las dos razas como ente social.

Siguiendo el constructo teórico, Bajtín explica, sobre el concepto de novela, que su estructura es un conjunto no sólo de régimen lingüístico, sino que aborda, en su contenido narrativo, una serie de sentidos, que pueden encontrarse en el argumento central:

El argumento mismo está subordinado a esa tarea de correlación y revelación recíproca de los lenguajes. El argumento novelesco debe organizar la revelación de los lenguajes sociales y de las ideologías; debe mostrarlos y probarlos: la puesta a prueba del discurso acerca de la concepción del mundo y del hecho motivado ideológicamente, o la exposición de la vida corriente de los universos y micro universos sociales, históricos y nacionales (novelas descriptivas, costumbristas y geográficas), de las edades y las generaciones en relación con las épocas y universos ideológico-sociales (novela pedagógica y formativa). En una palabra, el argumento novelesco sirve como representación de los hablantes y de sus universos ideológicos. En la novela se realiza el reconocimiento del lenguaje propio en el lenguaje ajeno, del horizonte propio en el horizonte ajeno. Tiene lugar la traducción ideológica del lenguaje ajeno, la superación de su carácter ajeno, que no es más que accidental, externo y aparente. A la novela histórica le son características la modernización positiva, la supresión de las fronteras de los tiempos, el reconocimiento del eterno presente en el pasado. La creación de las imágenes de los lenguajes es la tarea estilística principal del género novelesco ${ }^{21}$.

Es importante clarificar que el anterior planteamiento tiene concordancia con uno de los temas de la novela y su estructura en prosa, ya que la esencia argumental de Eclipse de luna se desarrolla de la siguiente manera:

Como se resaltó antes, Joaquín es un hielero de procedencia indígena del municipio de Cumbal, que viaja a Barbacoas ${ }^{22}$ en busca del tesoro de su padre,

21. Bajtín, Teoría y estética de la novela, 181.

22. En la página 57 de la novela Eclipse de luna, existe un acontecimiento histórico clave, que sirve para entender la procedencia ancestral de sus pobladores, cuando su protagonista lee un libro llamado: Reseña histórica de Barbacoas, Tierra de oro, texto que existe, en la realidad, cuyo autor fue Gonzalo Guerra Angulo. 
que está oculto en una casa sacerdotal, y contiene un Cristo y un rosario de oro, valor suficiente para que él y su familia solventen su situación precaria de pobreza. Cuando llega a su destino, Joaquín olvida por completo su misión, pues conoce a Yemeyá, una afrodescendiente que recolecta oro en el río Güelmambí; los dos se enamoran, llegan al acto nupcial y tienen un hermoso, hijo llamado Luther Nelson. Pero, luego de varios meses, no todo es felicidad como al principio, pues Yemeyá se entera de que tenía cáncer de mama; luego, sin un tratamiento médico avanzado, hizo metástasis, lo que lo expandió por todo su cuerpo, sin que, para detenerlo, se produjera milagro alguno. Al trascurrir medio año de consternación y dolencia, los médicos de la capital de Nariño le informaron que le quedaban pocos meses de vida. Yemeyá decidió regresar a Barbacoas para morir en su tierra natal y no en uno de los desagradables hospitales de Pasto. Al llegar a su comarca, el proceso finaliza en su irrevocable muerte. Joaquín, sin más remedio, regresó a Cumbal al lado de su familia, sin el Cristo ni el rosario de oro, pero sí con un invaluable tesoro, que los hará felices por el resto de su vida: Luther Nelson.

Para valorar los apartes narrativos de la novela, se realizó la siguiente secuencia, al entrelazar dos niveles etnoliterarios en los protagonistas "subalternos":

El sol y la luna programan su unión a las tres de la mañana, cuando Joaquín se levanta para ir en busca de infortunios a la montaña blanca de Cumbal con su padre Floresmilo Chinguad. Desayunan tortillas con café endulzado con panela antes de emprender la hazaña; piden prestado un caballo para el trajinar. El viento es su peor enemigo en cada escalón porque la montaña sacude su alfombra escarchada para que sus cuerpos se congelen en el ascenso; "el viento ataca, brama, ruge, helando las orejas y las manos, pasmando las ropas (...) El sol es una luna que no calienta" ${ }^{23}$. Luego de un lapso de 10 horas, lograron obtener su 'oro blanco' y, al bajar de la cima, lo vendieron en la plaza a Misia Blanca, que hace chupones y helados de paila. Joaquín regresó a su vereda con su padre, con el escaso dinero que les alcanzaba apenas para una barra de jabón, una marqueta de manteca de borrego, una libra de sal, café y un kilo de arroz, que son los únicos productos alimenticios que mitigan el hambre de esta familia cumbaleña.

En esa constante lucha devastadora de esperanzas por sobrevivir, llega una carta a las manos cansadas de papá señor, la que cambia el destino de la vida de

Ricardo Estupiñán toma como referencia este estudio, específicamente la página 5, donde Joaquín, en la novela, descubre que los fundadores de esta localidad fueron "los indios iscuandés, saquiangas, tapajes, barbacoas y telembíes, [que] se dedicaban a la agricultura, a la pesca y a la minería de los admirables yacimientos de oro", antes de la llegada de los españoles, porque, luego de la Conquista, los colonos mandaron a traer negros de África, al ver que los indios no resistían las jornadas de explotación de oro; este hecho explica el porqué de la raza afrodescendiente en Barbacoas.

23. Estupiñán, Eclipse de luna, 12-15. 
Joaquín, pues en ella se encontraba un secreto formidable: un tesoro que contiene un Cristo y un rosario de oro, ocultos en la casa sacerdotal de Barbacoas, misión que el hielero decide emprender como una nueva osadía, pues era la oportunidad para que él y su familia tuvieran una vida digna, mejor de la que les había tocado vivir: "no sé cómo haré, pero estas manos traerán ese tesoro" ${ }^{24}$.

Joaquín se dirigió a Barbacoas para obtener la fortuna, lo que le generó una inusitada felicidad a su padre, pues creía que, con la riqueza que obtendrían, iban a cambiar sus vidas; "si traigo el caudal, la vida de papá señor y la de todos cambiará y no tendrán que bajar más nieve"25. Al llegar, observó que el lugar era disímil a las descripciones planteadas por su padre: "no sé dónde estará la riqueza que dice papá señor; es un pueblo grande y miserable"26; ahora, la vida de Joaquín cambiará por completo.

Joaquín, cuando llegó a Barbacoas, describió perfectamente el clima sofocante, que para algunos puede ser exagerado, pero real. Al ser un descendiente indígena de una región de clima frío, a él se le dificultaba un poco adaptarse, porque es drástico este tipo de cambio inesperado en su vida:

En medio día llegamos a Barbacoas; todo es distinto, casas de tabla sin cepillar, techumbres de cinc, pavimento destruido, desorden, morenos por todas partes. No sé en dónde estará la riqueza que dice Papá Señor; es un pueblo grande y miserable. Los pasajeros desmontan. El bus entra en el Terminal. Soy el último en bajar; el calor derrite el suelo; esto es un horno abierto. Los carros oxidados circulan en cualquier dirección. Tomo una calle y transito; cientos de estudiantes negras irrumpen en las aceras con sus risas; la Normal está frente a mí. Al lado izquierdo una plaza, una iglesia; deambulo hacia abajo; me encuentro con un impresionante río de color verde, muy ancho; en su orilla varias embarcaciones repletas de frutas. Me siento en las gradas calientes; estoy desorientado, tengo hambre y no sé cómo empezar. Sobre el andén, dos mujeres negras sobreasan pescado; su olor despierta mi estómago ${ }^{27}$.

Las características de precariedad son evidentes; este fragmento es una muestra en la que se puede analizar la pobreza que contempla la región y la parte climatológica se describe a través de una serie de imágenes e hipérboles que caracterizan su sentido. De igual forma, se puede identificar un tono no despectivo cuando Joaquín Senderos se refiere a las personas afro con el término "negro"; por ejemplo: "los negros en los andenes juegan dominó y toman cerveza"; de esta manera, la novela suscita un respeto entre razas.

24. Estupiñán, Eclipse de luna, 26.

25. Estupiñán, Eclipse de luna, 27.

26. Estupiñán, Eclipse de luna, 46.

27. Estupiñán, Eclipse de luna, 45-46. 
Pues bien, la anterior secuencia permite esbozar una breve explicación sobre el contenido de la novela Eclipse de luna de una forma central; es decir, no explicita de manera concreta uno de los temas primordiales presentes en la obra, como los fundamentos subalternos. A propósito de esto, Bajtín expresa:

Durante mucho tiempo, la novela sólo ha sido objeto de análisis abstractoideológicos y de una valoración periodística. Se eludían totalmente los problemas concretos de la estilística o se analizaban de pasada e infundadamente; la palabra de la prosa literaria era entendida como palabra poética, en un sentido estrecho, y se le aplicaban, de manera no crítica, las categorías de la estilística tradicional (basada en la teoría de los tropos), o bien, los estudios se limitaban simplemente a las características valorativas vacías de la lengua — «expresividad», «plasticidad», «vigor», «claridad», etc.- sin investir estos conceptos de algún sentido estilístico más o menos definido y racional ${ }^{28}$.

Por esta razón, para encontrar dicho objeto de estudio, se escudriñó a fondo los espacios narrativos. Estupiñán, a través de diversos personajes, ha puesto de manifiesto diferentes problemáticas de la vida social; entre ellas, compete enfatizar, en este apartado, la temática de la subalternidad que se evidencia en diversos capítulos de la novela. Por ejemplo, cuando Joaquín y su familia luchan por sus ideales y contra sus padecimientos, como la miseria y la explotación, utopías que el protagonista pretende solventar en su vida pero que lamentablemente no logra suplir en la historia. En este sentido, la narración no sólo se convierte en una representación de lo que trató la historia del esclavismo y la pobreza en Nariño, sino que lleva al lector a reflexionar sobre el discurso dominante de las hegemonías de Latinoamérica, especialmente en tierras colombianas.

Por otro lado, establece el valor de la vida indígena y la raza afro, al efectuar implícitamente una crítica literaria ante el discurso elitista de la colonia y el eurocentrismo; a aquellos discursos hegemónicos de poder que invadieron física y conceptualmente estos territorios y clausuraron la emancipación de los imaginarios culturales, sociales y religiosos de los subalternos. Eclipse de luna es una novela que Estupiñán escribió, precisamente, para crear conciencia sobre cómo vive la gente de Cumbal, en especial las familias indígenas que sobreviven escarbando hielo, cada vez más escaso, de un nevado; cómo sobreviven las familias que extraen el azufre de los cráteres del Cumbal para venderlos a un precio que apenas les alcanza para sobrevivir; cómo vive la gente que tiene que poner a sus hijos desde muy niños a trabajar en el martilleo de la piedra para sacar el triturado, como lo expresa el mismo Estupiñán en su entrevista realizada en el año 2009. Del mismo modo, lo efectúa con la comunidad afrodescendiente de

28. Bajtín, Teoría y estética de la novela, 78. 
Barbacoas que, a pesar de la pobreza, es muy alegre; que, a pesar de que las casas son de tablas y el techo de lata, viven y sobreviven en la alegría, en la música, en la marimba, en el trombón, conviven y comparten entre vecinos; $y$, obviamente, hay mujeres que trabajan sacando el oro, aún después de tantos años de extracción, y siguen sobreviviendo con lo que les dan el río Patía y el río Telembí.

\section{EL SIGNO SUBALTERNO EN ECLIPSE DE LUNA}

Como ya se mencionó en anteriores párrafos, los protagonistas de Eclipse de luna, Joaquín y Yemeyá son dos personajes que representan dos razas importantes del Departamento de Nariño: el indígena de Cumbal y el afrodescendiente de Barbacoas; los dos son subalternos, en el sentido en que han padecido situaciones de pobreza e injusticias sociales que no les han permitido enmarcarse en la élite social; no obstante, la sangre y la cultura que llevan en sus venas permiten incluirlos dignamente en la alternativa del cambio social.

Joaquín es un hombre que no le teme a los viajes, porque siempre piensa en el bienestar de su familia y anhela sacarla algún día de la pobreza. Es un joven que siempre ha estado oprimido por la desigualdad social que sufre Colombia; sin embargo, ama a su tierra natal, porque es su progenitora:

El cerro sigue desencapotado; su nieve retiene miles de estrellas que se desprenderán antes de la noche; miro los hilos de plata que bajan por la falda. Su boca muestra las fumarolas que se pierden en el espacio. Esta tierra es mi madre; yo soy este barro. El aire, el suelo, el cerro, forman parte de mi vida. Esta heredad guarda en paz las cenizas de mis mayores, su sangre y su esperanza; nosotros somos su semilla ${ }^{29}$.

Al igual que cualquier otra persona, siente y vive el dolor de su comarca; no sólo él es un subalterno; su familia y su pueblo también lo son; asimismo, vive la pobreza y los trabajos inhumanos:

(...) más abajo, un montón de chiquillos trabajan en las minas; sus pequeños cuerpos levantan grandes mazos; pican las rocas hasta triturarlas; sus semblantes se apagan con el cansancio; son niños de ocho años haciendo la labor de los grandes, y no les pagan; sus manos lastimadas, los hombros deformes y sin tiempo para soñar, ni jugar. Quién penará más: mis hermanos en la nieve, o estas criaturas que golpean sus martillos en la piedra. Niños trabajadores, expuestos al sol y al agua, pedacitos de sudor. Nacimos para el dolor y el trabajo desde chiquitos.

Senderos es el apellido metafórico de Joaquín, porque su vida siempre ha sido un viaje; cuando se dirige a Barbacoas, observa en las carreteras otro tipo

29. Estupiñán, Eclipse de luna, 29. 
de padecimientos: "El bus ruge bajando por una vía de curvas; hay muchos indigentes en la carretera, soportando atadijos de leña en sus espaldas, vapuleando chivos" $^{\mathbf{3 0}}$. Cuando llega a Barbacoas, el Padre Mario Riascos le pregunta sobre su misión, porque todos los jóvenes que llegaban a esta localidad trabajaban como 'raspachines'. Este es otro aspecto clave para entender la subalternidad en la novela, ya que revela la situación que vivió hace algunos años el Departamento de Nariño; con el tema del "oro blanco", muchos campesinos se dedicaron a sembrar cultivos ilícitos, como la coca, la amapola y la marihuana, porque preferían ganar más dinero en menos tiempo. Durante esas épocas, algunos municipios fueron minas de oro; niños, jóvenes, adultos y ancianos tenían el anhelo de salir de la pobreza con esta clase de trabajos.

Estupiñán critica fuertemente las injusticias sociales y el tema de la subalternidad:

El calor agrieta las tablas de la pequeña capilla, la ceremonia comienza, los morenos rezan con devoción al mismo dios blanco en cuyo nombre los esclavizaron hace cinco siglos. Repiten golpeándose el pecho, por mi culpa, por mi culpa, por mi gran culpa. Se confiesan de todos los pecados cometidos hasta hoy y prometen firmemente no volver a pecar. Los que deberían pedir perdón y enmendar sus faltas son otros: los ricos, la iglesia y los gobiernos ${ }^{31}$.

A pesar de que la vida de Joaquín, en Barbacoas, cambió, en el sentido de enamorarse de una hermosa mujer negra, él no olvidó a su familia, que estaba congelándose de hambre; debía encontrar lo más pronto posible el tesoro enterrado, pero el delirio de su amor postergó esa tarea, para regresar a su tierra natal sólo con el pensamiento:

Las nostalgias vienen a mi memoria, mis hermanos, mis paisanos, pobres de solemnidad, caminantes de la vida, indocumentados en su propia tierra, sin ropas, sin sal y sin pan, sobrevivientes del despojo, peones, niños trabajadores, banderas desteñidas de una patria que no nos quiere. El dolor se une a la recordación ${ }^{32}$.

Yemeyá. Su nombre significa la deidad que representa el principio materno; es la madre del mundo, la señora de las aguas y la reina de los mares, fuente fundamental de la vida. En la novela, simboliza a una raza muy importante para el continente latinoamericano, pues es hija de la Costa Pacífica de Colombia, pero también tiene raíces africanas. En su sangre y en su alma alberga toda una

30. Estupiñán, Eclipse de luna, 34.

31. Estupiñán, Eclipse de luna, 57.

32. Estupiñán, Eclipse de luna, 72. 
historia pura de los afrodescendientes, que ha sido aislada de la sociedad, sin saber que su legado cultural, como la música, es admirable.

Al seguir los estudios de Friedemann, se sabe que las legiones negras "entraron al país en el siglo XVIII, exactamente a partir de 1700, año en el cual la minería de oro tomó un inusitado auge en el Chocó y en otros lugares de la costa Pacífica" ${ }^{\prime 3}$, entre ellos Barbacoas, y su abundancia del metal dorado en sus ríos Güelmambí y Telembí. Desde ese entonces, los negros, que trabajaban en las cuadrillas en busca de oro, deseaban como único pago una valiosa moneda que cualquier persona desea recibir: la libertad. Sin embargo, cuando los españoles llegaron a lo que luego sería Colombia, recurrieron a los indios para este tipo de trabajos, lo que incluía a la ganadería y la agricultura; al ver que ellos no rendían en las arduas jornadas de trabajo, trajeron de África a muchos negros, pero sólo como herramientas de trabajo, no como portadores de cultura.

En Colombia, se estableció el derecho a la diversidad: "en junio de 1993 en la Ley 70, en el marco de una nueva Constitución, que en 1991 definió a la nación como un ente pluriétnico y multicultural" ${ }^{34}$; tanto a los indios como a los afrodescendientes, se les legitimaron sus status étnicos, territoriales y culturales. No obstante, en la actualidad aún siguen siendo explotados en diferentes sentidos: siguen siendo subalternos, ya no de la burguesía española, pero sí de aquellos discursos hegemónicos que pretenden excluirlos de las venas latinoamericanas.

Yemeyá proviene del linaje africano; en la novela, se puede ver explícitamente cómo muestra su tradición por medio del baile, la rutina, la fiesta, las prácticas sagradas (ritos), lo profano y lo funerario, que sustentan el átomo heterogéneo de la cultura nariñense:

Aunque los africanos en la trata llegaran desnudos de sus trajes, armas y herramientas, desposeídos de sus instrumentos musicales y de bienes terrenales, por fuerza traían consigo imágenes de sus deidades, recuerdos de los cuentos de los abuelos, ritmos de canciones y poesías o sabidurías éticas, sociales y tecnológicas ${ }^{35}$.

Entonces, ¿por qué se afirma que este acervo cultural desapareció, para propagar únicamente la cultura europea en Latinoamérica? Es una aseveración inadmisible; o, qué decir del siguiente fragmento de Eclipse de luna:

Mil puñaladas hieren mi corazón. Doña Clementina quiere ponerse a rezar; al oído le pido que no; ella aún respira; le digo 'mejor, cuéntenos de

33. Nina de Friedemann. La saga del negro (Bogotá: Universidad Javeriana, 1997), 12.

34. República de Colombia, Constitución Política de Colombia (Bogotá: Base de datos políticos de las Américas, 1991), 22.

35. Estupiñán, Eclipse de luna, 91. 
la infancia de mi mujer'. Ella acepta y narra muchas historias de alegrías y travesuras. Humedezco un algodón en limonada helada y lo exprimo sobre los labios de Yemeyá. Le digo que hemos decidido viajar al África; el niño tiene que conocer la cuna de sus abuelos, traer los tambores para despertar a los espíritus y volar sobre ríos, mares y montañas, detrás de la nube más linda, que es nuestra Yemeyá ${ }^{36}$.

\section{EL CRONOTOPO, LA HETEROGLOSIA Y LA HISTORIA EN ECLIPSE DE LUNA}

El cronotopo es, para Bajtín, "la conexión esencial de relaciones temporales y espaciales asimiladas artísticamente en la literatura" ${ }^{37}$. Plantea que, para su clasificación, se debe tener en cuenta tanto el acumulado de motivos como el medio metafórico-simbólico de la novela, insertos en la cultura, ya que dicha estructuración permite comprender el espacio y el tiempo como dos condiciones de carácter social, que interactúan dialógicamente. El cronotopo, según este autor, se genera desde el punto de vista artístico-arquitectónico de la visión del mundo en su tiempo y espacio; dichos supuestos los ejemplifica por medio de las aventuras de los héroes en la novela griega clásica, donde el tiempo no se calcula adecuadamente, pues los minutos, las horas, las semanas, los meses y los años no se ven proyectados en la edad de los personajes. Por esta razón, el tiempo real es necesario dentro de un argumento, por lo que Bajtín considera que el espacio debe ser extenso, para que la trama se desarrolle de una forma convincente, ya que en absoluto puede haber reflejo de una época fuera del curso del tiempo, de las vinculaciones con el pasado y el futuro, de la plenitud del tiempo. Cuando no hay paso del tiempo, tampoco existe aspecto del tiempo, en el sentido pleno y esencial de la palabra ${ }^{38}$.

Desde esta perspectiva, para entender el cronotopo presente en la novela de Estupiñán, es necesario interpretar el tiempo y el espacio a lo largo de la historia de una forma metafórica; dicho sentido parte desde el apellido que tiene el protagonista de la novela: Senderos. Al mencionarlo, se puede determinar que es un hombre de aventura, que recorre diferentes caminos, tal y como lo hizo Odiseo en busca de lo otro. Joaquín, al emprender un nuevo viaje rumbo a Barbacoas y al interpretar con su charango La pastora de los Chasquis, como un medio musical, deja atrás, en su comarca, una esperanza de volver; sin embargo, la música andina no es suficiente para refugiarse en los recuerdos, pues el tiempo se convierte en un factor de nuevos comienzos para él; es decir, de nuevos caminos para andar. Al llegar a Barbacoas, en 1999, conoce a la deidad del mundo, cuyo nombre es

36. Estupiñán, Eclipse de luna, 137.

37. Bajtín, Teoría y estética de la novela, 273.

38. Bajtín, Teoría y estética de la novela, 298. 
Yemeyá; con el trascurrir de las semanas, Joaquín recuerda a su familia entre pensamientos y sueños, pero no es suficiente para que retorne a su tierra, pues hay otros intereses que hacen que no exista un pasado o un presente; sólo un futuro: el de estar con su morena, a la que no puede faltar, así haya un tesoro de por medio; "el sol de las cinco de la tarde me encandila. El canoero viene por mí; me monto; antes de partir observo a la joven que ni siquiera advirtió mi presencia; el retorno dura veinte minutos; los gasto pensando en ella"39.

Senderos congela el tiempo a través de su mundo onírico, para estar por siempre con su amada, en un viaje que no tiene límites:

La sueño junto a mí; soy el dueño del mundo en este anochecer; busco sus ojos; caminamos por el filo hasta el borde final; una luz nos hace eternos y dioses. Este sendero sin muerte nos guía por las estrellas y en el centro mi nubecita negra, pluma de gaviota oscura. Sus pies hacia el mar, arrullándola en una cuna africana ${ }^{40}$.

Senderos, como subalterno, va siempre hacia adelante, en busca de un mejor bienestar, y con Yemeyá encuentra un lugar diferente y un nuevo color para su mundo. Los dos se enamoran, pierden la noción del tiempo y, con la llegada del nuevo milenio (año 2000), procrean a un ser, fruto de la unión de dos espacios diferentes: sus razas.

Estupiñán utiliza, en su novela, un epígrafe, en las primeras páginas: "por el derecho a morir dignamente", y en su mensaje implícito está una voz de reclamo ante los abusos que lo urbano manifiesta hacia la periferia. En Eclipse de luna, se exterioriza una subalternidad cronotópica, un régimen hegemónico, y es el caso en el que Yemeyá, al viajar a un mundo distinto al de ella, un mundo citadino que rechaza su condición racial, agota sus últimos alientos de vida en la ciudad de Pasto, donde no le prestan la atención que requiere su enfermedad, un cáncer, que la lleva a luchar contra el tiempo, puesto que día a día su agonía es más vigente.

El espacio de la capital de Nariño se convierte en un mundo siniestro, donde el hospital que atiende su caso la hace morir en vida. Joaquín la acompaña en su lucha, pero el tiempo es más rápido y comienza a arrasar con la belleza de Yemeyá; el cáncer devastó primero su seno derecho, luego su cabello y posteriormente su pierna, se propagó por el resto de sus extremidades y de su alma, un dolor que ni todo el oro del mundo puede sanar. Luther Nelson es cada vez más grande, pero aún no comprende el dolor de su madre; ella le escribe una carta donde le expresa todo su amor, porque su muerte se aproxima y, a pesar de que no lo verá crecer, entre sus anhelos quiere que sea un hombre libre. Senderos

39. Estupiñán, Eclipse de luna, 64.

40. Estupiñán, Eclipse de luna, 82-83. 
regresa después de seis años a Cumbal, donde lo único que encuentra es la vejez de sus padres, que le sonríen al ver que su hijo encontró un tesoro que alegrará por siempre el corazón de toda la familia.

La novela Eclipse de luna, a diferencia de otras novelas de Nariño, maneja ciertas temáticas que, sujetas a la normatividad textual, atrapan al lector con su trama; de aquí que el amor, el sufrimiento y la muerte, confluyen en un mismo entrelazamiento cronológico, que articula una cronotopía particular, que se encuentra relacionada con el concepto de subalternidad, el cual tiene inmerso un matiz interpretativo, que se identifica con la historia colonial de América Latina y sus fracasos de liberación física y conceptual. Sin duda, el amor es uno de los ejes centrales de la historia, puesto que no sólo se aprecia este sentimiento hacia una persona en común, sino que también manifiesta otros aspectos metafísicos e inmateriales que dan mayor relevancia al texto literario, como es natural, al saber que Joaquín se enamoró apasionadamente de Yemeyá. De igual forma, el paisaje, la música, la gente, la comida y el clima del Pacífico, lo enamoraron y generaron en él un amor sin objeto de deseo, tan natural que este personaje se olvidó por completo de su objetivo: encontrar el tesoro que los sacaría de la pobreza, a él y a toda su familia cumbaleña.

Con respecto a la heteroglosia, Bajtín, en su libro Teoría y estética de la novela, considera que este tipo de texto narrativo es un fenómeno pluriestilístico, plurilingüe y plurivocal. A través de un plano lingüístico, otorga características heterogéneas, diversos elementos sonoros y semánticos que se asocian a los discursos de los personajes. Sus planteamientos apuntan a que sólo al analizar el campo discursivo de los personajes en una novela, se pueden hallar múltiples significados que, en su conjunto, configuran una esfera semántica de una determinada sociedad.

Según la estilística tradicional, este tipo de aspectos pasaban desapercibidos en la interpretación textual, al limitarse a una recepción de los rasgos superficiales de la obra (sujeto, verbo, espacio y tiempo). En Eclipse de luna, se puede destacar una estilización que la hace diferente respecto a otras novelas nariñenses, porque en su contenido está inmersa la tradición oral de dos poblaciones: Cumbal y Barbacoas. Sus expresiones semi-literarias se encuentran representadas por tropos; en su lenguaje extra-artístico no hay límites entre géneros literarios (hay cartas y letras de canciones); el lenguaje individual de los personajes (heteroglosia) es una variante que configura la riqueza dialectal de Nariño; dichas unidades estilísticas heterogéneas, al combinarse, forman un sistema armonioso en esta novela, que Bajtín define como polifonía.

El lenguaje utilizado por los personajes en Eclipse de luna es supremamente importante; es un vehículo de comunicación, un instrumento por el cual se 
verifica la comunicación racial (indio, negro) fundamental para interpretar su contenido; por tanto, entre los elementos más importantes de la cultura de Nariño está el sistema lingüístico, su alcance y proyección, su nivel de elaboración y sus resultados. La cultura se transmite por diferentes rutas, pero la más directa, la que está presente en todas ellas es la palabra, el intercambio coloquial y el discurso sub-estandarizado. Por ello el lenguaje de la novela también se dignifica con diversas expresiones nativas heterogéneas, como es el caso de los quechuismos que aún se conservan en el habla nariñense, lo que hace que la obra retome las características de lo que Cornejo Polar, en sus estudios literarios, denominó como 'novela aborigen y popular'; por ejemplo: "Poco a poco nos encaramamos en la cima del Cumbal, repitiendo achichay a cada segundo" ${ }^{\text {"1 }}$. Al respecto, Montes señala:

El habla, como lengua en funcionamiento, es esencialmente móvil, dinámica y continuamente está haciendo entrar en la lengua elementos nuevos que se convencionalizan (se hacen lengua); la lengua nunca puede permanecer inmutable mientras funcione en la sociedad histórica, pues cada individuo que la utiliza le comunica algo de su modo de ser individual, tanto por el temperamento de cada persona, como porque cada nuevo individuo pertenece a un tiempo diferente al de sus predecesores ${ }^{42}$.

Según la afirmación de Montes, la lengua cambia porque revela la ininterrumpida evolución de la sociedad; sin embargo, se puede observar que, en la novela Eclipse de luna, todavía se mantienen locuciones prehispánicas, términos legítimos de las lenguas nativas de Los Andes. El anterior quechuismo, que menciona Joaquín, es un vocablo para expresar que está haciendo "frío"; esta interjección, según Pazos, aparece morfológicamente como "achachay" ${ }^{43}$, lo que significa que el autor la escribió como se habla naturalmente en la región, al igual que "chalina" (manto para las mujeres), chumar (tomar), y guagüita, que proviene de la voz quechua "wawa", que significa niño.

Entre otros términos característicos de Nariño que están presentes en la novela y en los que Estupiñán colaboró con la información de sus respectivos significados, están: aterido (entumido), cabuya (soga), canjilones (huecos que se forman en el camino), chancuco (bebida alcohólica), cincha (correa que ata la albarda), curiosear (averiguar algo), chiguanquiar (amanecer de un nuevo día), chiquillo (joven), chillar (llorar), crío (bebé), fardo (carga o envoltorio de nieve), fosca (viento fuerte), guambra (joven), guasás (instrumento del Pacífico, elaborado con guadua y semillas secas), juerga (diversión), merienda (comida), mullupa (objeto para guardar joyas), pitecito (sinónimo de pedacito) y sarao (festejo).

41. Estupiñán, Eclipse de luna, 13-14.

42. José Montes. Dialectología general e hispanoamericana (Bogotá: Instituto Caro y Cuervo, 1995), 43.

43. Arturo Pazos. Glosario de quechuismos colombianos (Pasto: Caza de libros, 2012), 61. 
Se sabe que, en la actualidad, algunos términos son poco usuales; no obstante, se registran en esta obra con el propósito de revelar lo espacio-temporal y el nivel histórico-social del individuo por medio de sus actos comunicativos. De esta manera, Bajtín define este tipo de código lingüístico como heteroglosia: los diferentes lenguajes o expresiones en la novela. Existe una multiplicidad de intercambios verbales, los cuales se entrelazan con la cultura popular de los personajes, que deben condicionar sus lenguajes según las necesidades comunicativas, como se puede apreciar en los estudios de Bajtín (p. 13), donde "las palabras del héroe rompen el plano monológico de la novela y provocan una respuesta inmediata, como si el héroe no fuese objeto del discurso del autor, sino el portador autónomo de su propia palabra"44; por ello considera a Dostoievski el creador de la novela polifónica. Lo mismo ocurre en Eclipse de luna, porque su lenguaje heterogéneo entre dos razas, destruye la unidad monológica, siempre y cuando los personajes no encarnen la misma visión del mundo, al producir un singular tono polifónico, representado en la oralidad, el testimonio y la música.

De lo anterior, Bajtín relaciona el término de la heteroglosia dentro del género novelístico:

La novela es la diversidad social, organizada artísticamente, del lenguaje; y a veces, de lenguas y voces individuales. La estratificación interna de una lengua nacional en dialectos sociales, en grupos, argots profesionales, lenguajes de género; lenguajes de generaciones, de edades, de corrientes; lenguajes de autoridades, de círculos y modas pasajeros; lenguajes de los días, e incluso de las horas; social-políticos (cada día tiene su lema, su vocabulario, sus acentos); así como la estratificación interna de una lengua, en cada momento de su existencia histórica constituye la premisa necesaria para el género novelesco; a través de ese plurilingüismo social y del plurifonismo individual, que tiene su origen en sí mismo, orquesta la novela todos sus temas, todo su universo semántico concreto representado y expresado. El discurso del autor y del narrador, los géneros intercalados, los lenguajes de los personajes, no son sino unidades compositivas fundamentales, por medio de las cuales penetra el plurilingüismo en la novela; cada una de esas unidades admite una diversidad de voces sociales y una diversidad de relaciones, así como correlaciones entre ellas (siempre dialogizadas, en una u otra medida) ${ }^{45}$.

En esta fase, el discurso narrativo de Estupiñán y los lenguajes de los personajes son composiciones fundamentales para comprender el plano plurilingüístico de Eclipse de luna; este tipo de unidades verbales muestra la dialogización social de Cumbal y Barbacoas, que destacan la heterogeneidad literaria de Nariño. Entre la interacción de los dialectos de Joaquín y Yemeyá, existen varios términos plu-

44. Mijaíl Bajtín. Problemas de la poética de Dostoievski (México: Fondo de Cultura Económica, 1986$), 13$.

45. Bajtín, Teoría y estética de la novela, 81. 
rifónicos que descanonizan el lenguaje europeo que se pretendió imponer como lengua matriz ante las múltiples comunidades de habla nativa; dichas expresiones se mantienen vivas en el lenguaje de la prosa de su novela; cada terminología, en su campo semántico y contextual, sustenta significados exclusivos.

Por otra parte, algunos críticos se han equivocado al mencionar que la literatura es sólo ficción; también es un recurso para volver a contar la historia de los grupos humanos; como lo afirma Fernández, "cada estado social trae su expresión a la literatura, de tal modo que por las diversas fases de ella pudiera contarse la historia de los pueblos, con más verdad que por sus cronicones y décadas" ${ }^{\prime 46}$. En relación con la parte histórica en la novela Eclipse de luna, Jauss expresa:

La hermenéutica literaria tiene "la doble tarea de diferenciar metódicamente las dos formas de recepción: es decir, la de aclarar, por un lado, el proceso actual, en el que el efecto y la significación del texto se concretizan para el lector del presente, y la de reconstruir, por otro, el proceso histórico en el que los lectores de épocas distintas han recibido e interpretado el texto siempre de modo diferente ${ }^{47}$.

En otros términos, Fernández alude a lo importante que es la literatura en la historia y viceversa:

Frente al ahistoricismo paraformalista, es imprescindible subrayar con energía este criterio, que comparto: historia y crítica literarias son como anverso y reverso de una misma tarea: es irrealizable una historia literaria que pretenda carecer de valoración crítica; y es inútil o insuficiente una crítica que se postule desvinculada de la historia: así como ambas mantienen relaciones esenciales con la correspondiente teoría literaria ${ }^{48}$.

Estupiñán creó dos personajes: Joaquín y Yemeyá, para describir las costumbres de dos razas, y por ello, en su reportaje del 5 de agosto de 2013, expresó: "los protagonistas son rescatados de sus etnias. Nuestro Departamento mestizo está conformado por el $20 \%$ de afrodescendientes y $15 \%$ de indígenas; sin embargo, su inclusión social, académica, económica y política ha sido deficiente. Ellos, como el resto de la población, también tienen su historia". Además, realiza una crítica, en su novela, sobre los procesos minoritarios que padecieron las dos culturas nariñenses: Cumbal y Barbacoas. Para él fue importante destacar dichos aspectos en su novela:

La historia y sus protagonistas hacen parte de la realidad colombiana. No olvidemos que los indígenas son nuestros hermanos mayores. Ellos son los primeros pobladores de América y fueron despojados de su tierra y

46. Fernández, Para una teoría de la literatura hispanoamericana, 50.

47. Jauss, Experiencia estética y hermenéutica literaria, 14.

48. Fernández, Para una teoría de la literatura hispanoamericana, 
todo lo que ella les daba; los afro, fueron traídos violentamente de su vida normal en el África, a producir el desarrollo. Cada indígena, cada moreno, representa nuestro pasado.

Entre otros aspectos, es factible resaltar el siguiente fragmento de la novela, lo cual describe y recrea cómo vivió un subalterno en estas regiones:

- Papá señor se frota las manos y nos habla pausadamente:

Cuando yo era guambra acompañaba a mi papacito con las recuas a Barbacoas; nos demorábamos quince días a pata limpia; caminábamos hasta dieciséis horas diarias; descansábamos en las pascanas; mi papacito jalaba las bestias abarrotadas de quesos, papas, cobijas de lana, carne salada, cebada. De vuelta a Túquerres, cargábamos las mercancías de los barcos de vapor que venían del Pacífico por el Patía y el Telembí; esas naves traían pianos, molinos, muebles, vinos, enlatados, lámparas, calzado, vajillas. También transportábamos oro y platino de Barbacoas. Todo a lomo de mula. En una ocasión, mi papacito soportó en su espalda al cura español Fabián Guaristi Locadio, flaco, alto, blanco y muy simpático. El padre lo buscaba a mi papacito porque no brincaba; así podía leer sentado en una silla atada al espinazo de mi papacito. Yo trotaba y por ratos me abalanzaba en las bestias. El gentío llenaba las trochas, arrieros para abajo y para arriba, recuantes de pies anchos y rajados, peones conciertos. Los señores blancos iban montados en los lomos de los indios y de los negros. Los negros ya eran libres, pero seguían sirviendo... nosotros nunca fuimos esclavos, pero nacimos cargando ${ }^{49}$.

A través de este fragmento, se puede corroborar que sí hubo procesos hegemónicos en la región de Barbacoas, tanto con las comunidades afro como con los indios que también vivían en este sector; el autor incluyó en su narrativa parte de la historia que enmarca lo sincrónico de dichas posiciones geográficas. Este aspecto es válido, porque precisamente la literatura permite contar la historia de otra manera. Lo mismo sucedió en el municipio de Cumbal, pues, como lo expresa Guerrero, “desde las primeras épocas del descubrimiento y conquista, los indios fueron esclavizados y despojados de sus tierras; numerosas denuncias formularon ante el rey y el Consejo de Indias, solicitando respeto y protección ante la violenta expropiación que los dejaba sin este importante medio de producción" ${ }^{\mathbf{5 0}}$. No obstante, se mantuvo la hegemonía española, pues, en los años de 1535, Sebastián de Belalcázar, en busca de El Dorado en este territorio de los Pastos, facultó a Lorenzo de Aldana para que impusiera la encomienda, o sea, la repartición de indios para el trabajo de las tierras. Al respecto, Guerrero asevera:

Como lo hemos dicho, los indios fueron objeto de excesos, atropellos y desmanes cuando les cobraban los tributos; por eso, la corona adoptó la

49. Estupiñán, Eclipse de luna,

50. Guerrero, Estudios sobre el municipio de Cumbal, 90. 
medida de «tasarlos»; es decir, calculaban la capacidad de pago, la cantidad de animales y productos que podían criar y cultivar o «tasaban» el número de mantas que podían tejer y les obligaban a pagar el tributo que les fijaban dos veces al año, en junio y diciembre ${ }^{51}$.

En la actualidad, con los discursos posmodernistas, aún existen parlamentos oficiales que tratan de opacar la pluriculturalidad de los subalternos. En el cuerpo narrativo de la novela, se encuentran estos aspectos, ya que, de una u otra forma, el autor hace mención de lo racial, de la explotación de los indios y negritudes: "a los negros por idénticas razones a las que se los considera como animales de carga o para explotar las minas de carbón, ya que donde los indios se morían, metían a los negros". Por eso el crítico brasileño Antonio Cándido aduce sobre el proceso crítico que debe seguir el receptor en relación con los aspectos verídicos que puede sustentar una obra literaria en su contenido; en términos candidianos:

Un segundo tipo se podría formar con los estudios que procuran verificar la medida en que las obras espejan o representan la sociedad, describiendo sus varios aspectos. Es la modalidad más simple y más común, consistiendo básicamente en establecer correlaciones entre los aspectos reales y los que aparecen en el libro ${ }^{52}$.

Existe un aparte clave en la novela, en el que se puede ver la riqueza que tenía Barbacoas en la época en que Papá Señor trabajaba como sirviente en la casa cural, cuando tenía tan sólo quince años:

Barbacoas estaba levantada en una gran mina de oro. La quebrada Pichimbirá cruzaba el pueblo; allí se metían las negras con sus bateas y sacaban el oro; lo envolvían en sábanas de lienzo y lo pesaban por quintales en balanzas de madera con pesas de plomo. Se vivía en esa época; había ríos de oro ${ }^{53}$.

Este fragmento habla de hechos verídicos, que se manifestaron en este municipio; por ejemplo, el cortometraje histórico El oro es triste, de Bolivariana Films y Sánchez (1980), sustenta cómo la colonia española se benefició del oro explotado en el río Telembí, y describe la paupérrima situación que han vivido los pobladores de esta región, quienes paradójicamente coexistían con el oro, pero no recibieron beneficio alguno con la extracción del valioso metal. En términos más exactos, Sánchez afirma:

En los mapas antiguos ya se situaba un río en la parte sur de lo que hoy es Colombia, que despertaba la codicia de los conquistadores: Telembí. Éste

51. Guerrero, Estudios sobre el municipio de Cumbal, 71.

52. Cándido, Literatura y sociedad, 33.

53. Estupiñán, Eclipse de luna, 22. 
fue un río de oro; por siglos, las manos del hombre se hundieron en sus aguas buscando el supremo metal; primero fueron los indios sus dueños naturales; amasaron el oro, lo trabajaron, le dieron vida, perpetuando en él su cultura, sus creencias y, caso paradójico, tal vez el único oro que hoy nos queda es el de esos indios, que se guarda en el Banco de la República. Luego vinieron los españoles; durante cuatrocientos años y con el trabajo de los esclavos negros traídos del África le arrancaron oro al río para el fulgor de su imperio; después, con Simón Bolívar, los echamos; entonces, nos llegaron otros visitantes: los americanos.

¿Qué les ha dejado a los colombianos esta rapiña? A los negros del Telembí, su río pobre, destruido, saqueado; al país, el gran subdesarrollo. Estas gentes, descendientes de esclavos africanos, compiten así en la extracción del oro con las implacables dragas que de un solo bocado se llevan tanto como el trabajo de todos ellos en mucho tiempo. Escarbando en el agua, difícilmente logran sacar contaditas migajas de un oro que a los colombianos siempre se nos fue de las manos.

Barbacoas alguna vez tuvo su esplendor, en tiempos de la Colonia y hasta comienzos de este siglo; fue un importante centro comercial; hubo allí aristocracia, perfumes de Francia, encajes holandeses, lámparas de Baccarat; también tuvo esclavos, porque allí donde había oro, había esclavitud. Barbacoas conserva aún muchas tradiciones españolas y africanas y tiene un triste canto del pasado, con sus casas de dos pisos de ruinas y solas, como añorando tiempos mejores. La orfebrería barbacoana, extinguiéndose ya como tantas otras cosas allí; y pensar que Colombia producía el $40 \%$ del oro mundial; hoy la producción no llega al 1\% y no figura en las estadísticas. En un futuro no muy lejano, tendremos que importar oro hasta para las calzas de los dientes; ahora se dice que Colombia nacionaliza el oro, ¿cuál oro? Si el oro colombiano ya no existe, se lo llevaron; el oro colombiano ha muerto ${ }^{54}$.

Lo planteado en este cortometraje se corrobora con las afirmaciones de Guerra, que sostiene que el oro de este municipio lo saquearon los norteamericanos después de la Conquista. Por los años de 1935 y 36, se instalaba la compañía norteamericana con el propósito de explotar el oro que guardaba el río Telembí; iniciaron sus labores en una forma técnica, con una gran draga. La explotación minera con el método del dragado duró más de 37 años, pues terminó en 1975, tiempo en el que extrajeron, de su río y vegas, más de 30 toneladas de oro, que representaron miles de millones de dólares, para no dejar sino montones de piedras, las orillas destrozadas y las playas convertidas en rimeros de cascote y $\operatorname{lodo}^{55}$.

54. Luis Sánchez, Cortometraje Historia del oro en Barbacoas (Colombia: Bolivariana Films, 1980), disponible en: https://www.youtube.com/watch?v=3lfR1gonsqM (miércoles, 3 de abril de 2013).

55. Guerra, Tierra del oro, 21. 
Ante la situación de este municipio de Nariño, se hace un llamado de atención para que el gobierno nacional tome conciencia sobre los irresponsables actos que se están llevando a cabo, sin límite alguno. En esta óptica, es admirable apreciar lo que el autor de Eclipse de luna creó en algunos capítulos, espacios en los cuales se puede volver a soñar con una municipalidad que pervive en la armonía, en el amor y el jolgorio afrocolombiano.

Más adelante, la obra recupera un acontecimiento presente en la memoria de los barbacoanos; data del siglo XIX, en relación con el rescate de las joyas de la Virgen de Atocha, patrona de esta municipalidad:

En mil ochocientos veintiuno, el coronel patriota Ángel María Varela, siguiendo las órdenes de Bolívar, se presentó en Barbacoas con el fin de conseguir recursos para la gesta libertadora. Solicitó dinero a las familias más acaudaladas. No satisfecho con esto, se dirigió a la iglesia, cuyas imágenes tenían bellos ornatos de plata y alhajas, labrados en el Perú en mil ochocientos cuatro. Mandó a sus soldados a que tomaran en préstamo las joyas que cubrían los altares. Al cabo de cuatro horas, apiñaron dos quintales de plata del altar mayor y las pilastras interiores: tres arrobas de oro de las coronas, los rosarios, la pesada custodia y el delantal de la Virgen de Atocha, patrona de Barbacoas. La noticia del préstamo circuló como fuego a todas las damas del pueblo, quienes propusieron al Coronel cubrir entre todas el peso de las prendas de la iglesia; al día siguiente cumplían su propuesta: median en oro el equivalente del delantal sagrado, de la custodia y de todas las joyas, aretes, pulseras, anillos y cadenas.

Así, los oficiales patriotas retornaron los zarcillos, los collares, los prendedores, las cadenas, los cálices y ciento treinta y tres chispas de diamante. Devolvieron también, el rosario de oro, una de las vírgenes con amatistas y otra del niño con seis rubíes y una esmeralda con figura de aguacate. El coronel Varela pesaba en la balanza un chorro de alhajas, oro en polvo y en barra que salvaba las haciendas de la Virgen de Atocha. El rescate de las joyas de la Virgen revelaba los fabulosos caudales que corrían por los ríos de Barbacoas, el Telembí, el Patía, el Mangui (...) A pesar de ello, la tierra del oro y la libertad sobrevive encadenada a la miseria ${ }^{56}$.

Con este fragmento se puede aseverar que Eclipse de luna es una novela también histórica; resalta hechos de la Colonia y la Independencia que marcaron el devenir de Barbacoas y sus habitantes. El anterior acontecimiento, con respecto a la Virgen de Atocha, se puede estudiar también en las escasas fuentes históricas que existen sobre este municipio, tal y como aparecen en Tierra de oro de Guerra, al mencionar que Bolívar mandó a sus oficiales a recaudar estos impuestos porque necesitaba invertirlos en los gastos de la independencia del

56. Estupiñán, Eclipse de luna, 57-59. 
Perú; no obstante, las alhajas fueron rescatadas por parte de las mujeres de la ciudad en 1821, tal y como aparece fechado en la novela de Estupiñán.

\section{LA MÚSICA EN ECLIPSE DE LUNA}

Entre otros aspectos, la novela de Ricardo Estupiñán no tiene límites entre géneros literarios y la parte musical es una fuente primordial en su distribución narrativa, ya que el viento andino fluye en las melodías que versifican la quena y el charango de Joaquín. Para ejemplificar la poética musical en la narración, en la página 34, Joaquín menciona la primera canción en su trayecto rumbo a Barbacoas; es una composición de la argentina Soledad Pastorutti:

Voy por la montaña

hasta que me abrace el mar.

Por la Pachamama

que nos da la libertad.

Voy por los caminos

que nos llevan a la verdad.

La senda del indio

para toda la humanidad.

$\mathrm{Al}$ analizar este fragmento y escuchar la canción completa de la artista, se alude a la osadía de Joaquín en su vida, y recordar ese sentimiento de alegría al saber que es una persona de escasos recursos, pero libre; la canción rompe con los discursos hegemónicos, puesto que registra los valores que tiene el indio en su vida; sus sueños, anhelos y proyectos; el respaldo que tiene de la tierra, su progenitora. Luego, al aproximarse a la municipalidad de Barbacoas, oye una melodía de uno de los representantes de la música cubana, José "Pepito" Gómez:

La vida, cógela como venga;

escucha lo que te digo:

tú, no discutas con nadie,

hasta hacer un millón de amigos.

$P a^{\prime} q u e, p a^{\prime} q u e$ se te dé,

$P a^{\prime}$ que pueda bailarla,

$P a^{\prime}$ que se te dés.

Esta canción se refiere a los consejos que debe seguir Joaquín en su nueva vida, razón por la cual Estupiñán incorporó en su novela esta segunda canción

57. Estupiñán, Eclipse de luna, 47. 
para representar a la raza negra; un preámbulo para conocer cómo es la cultura afro de Barbacoas y el son que caracteriza a esta raza.

Posteriormente, al seguir revisando la novela, se encuentra una letra musical llamada Aprende a querer, del grupo Los Maraqueros de Oriente, que representa un sentir importante en la vida de Joaquín, quien está indudablemente enamorado de su compañera de sueños oníricos y reales: Yemeyá. En Barbacoas, este tipo de canciones son un legado; a sus habitantes les gusta escucharlas, por su descendencia negra; por ello la música cubana es clave en la vida de este grupo humano. En este fragmento de la novela, es evidente observar que Joaquín está totalmente enamorado de Yemeyá:

Entre el gentío y el estruendo penetro a mi cuarto para pensar paso a paso en el nuevo color de mi mundo. Las últimas gaviotas sobrevuelan los cielos.

Sueño con ángeles que detienen el tiempo; los dejo volar; veo barcos cargados de ángeles; huyen del dolor; flotan sobre el mar. Contemplo el barco; ya no estoy solo.

El sábado despierto pensando en Yemeyá, lunita oscura que aclara mi día. La voz del Telembí inicia su programación con los Maraqueros de Oriente: Aprende a querer, como te estoy queriendo. Aprende a morir, como me muero por ti. Aprende a sufrir, lo que hoy estoy sufriendo, por el amor, amor que siento por $t i^{58}$.

En esta medida, el protagonista, por medio de la musicalidad de ese nuevo día, aprende que el amor llega con los sueños que trae el aire; aprende a querer a una nueva raza, metaforizada en un nuevo mundo para él: un mundo negro.

Se acerca la Navidad y el género musical varía; la vida de Joaquín trascurre entre su trabajo y el amor por su media luna; se ha contagiado de la alegría, el calor y el sabor de la cultura afro y cada vez sus raíces se alejan, pero su esencia persiste en su corazón:

Cuelgo el charango, enciendo mi grabadora, escucho una canción andina de Illapu, me recuesto con su letra. Si queremos, podemos escribir la historia nueva... podemos inventar la luz del día, podemos hacer que el cielo se mueva, podemos construir con poesía ${ }^{59}$.

Si el mundo es diferente después de leer un poema, con una canción andina la vida se colma de naturalidad y creación; Joaquín pudo crear sus sueños y anhelos

58. Estupiñán, Eclipse de luna, 76-77.

59. Estupiñán, Eclipse de luna, 82. 
con el amor que tiene por su amada Yemeyá; él mismo lo afirma detalladamente, en el siguiente aparte:

En mi cuarto tomo mi viejo charango; sus cuerdas me hacen vibrar; lo he abandonado últimamente, pero es mi mejor amigo; me corteja con su música; en su pequeña caja encierra los mundos de Los Andes, el corazón de América; conoce mis emociones: el amor que es una duda permanente, mis pensamientos en la morena, las ganas de atarme a ella, a su locura, a su risa, a su ternura. Quiero quedarme con Yemeyá más allá de la razón, donde se atesoran los sueños, meterme en su alma y con ella monte adentro, al mundo de las guacamayas, entre duendes, niños y quimeras para decirle que la quiero, y crear un hijo entre los dos, lejos del invierno de mi tierra ${ }^{60}$.

Como se ve, Joaquín existe por medio de la música, y su contenido no representa lo 'sentimentaloide' o la cursilería, como otros lo llaman; todo lo contrario, manifiesta un conglomerado de situaciones que la humanidad debería sentir a diario. En la actualidad, son escasos esos tipos de escenarios de amor, que pasan a un segundo plano por dar prioridad a la búsqueda de un poder desmesurado, en todo sentido.

El ambiente de fin de año se propaga en Barbacoas y Joaquín no deja la oportunidad de festejar su amor en medio de los demás:

La música se ha tomado la ciudad; la gente está afuera; esto es un carnaval. Yemeyá se integra a las labores de la cocina; a cada momento me mira, sonríe. Hemos sellado nuestro pacto de amor, justamente el último día del siglo (...) retorno con unos tragos en mi cabeza. Yemeyá me recibe con un beso; las mujeres festejan a chillidos. La botella alcanza para cuatro vueltas. Las mujeres raspan el coco, exprimen su leche, la hierven, ponen el pescado en la olla y lo cubren con plátanos. El olor de la comida se mezcla con el ron. Ellas preparan, cocinan y bailan. La música las eleva. No necesitan nada más. Salgo por la segunda botella. Una trova de Rubén Blades genera el estrépito: Eres la canción que siempre quise cantar; eres la ilusión que nunca pude olvidar, que en todo momento vive dentro de mí y que, a pesar del tiempo, aún domina mi existir ${ }^{61}$.

Pero no todo termina allí; para concluir el fin de año, el Grupo Niche, con la canción La magia de tus besos, hace eco a la felicidad de Joaquín y Yemeyá, quienes deciden casarse; el ritmo salsero consagra el idilio de amor:

Si me besas en la boca ternura, si me besas al amanecer, si besas ya no queda duda, que nuestro amor es tan grande como el mar. En tus labios locos hay

60. Estupiñán, Eclipse de luna, 82.

61. Estupiñán, Eclipse de luna, 87. 
dulzura, un camino a la felicidad, entre paredes cruzamos un sueño, que no quisiera nunca despertar ${ }^{62}$.

Por otra parte, Yemeyá también recurre a la fuente musical para expresar sus más recónditos sentimientos, pero esta vez a su fruto más preciado: su hijo Luther Nelson. Ella le canta una composición de Mercedes Sosa que dice:

Como un pájaro libre de libre vuelo; como un pájaro libre, así te quiero. Nueve meses te tuve creciendo dentroy aún sigues creciendo y descubriendo. Descubriendo, aprendiendo a ser un hombre, no hay nada en la vida que no te asombre ${ }^{63}$.

Yemeyá, a través de esta melodía, le dice a su hijo indirectamente que la vida está llena de dificultades y adversidades, que se va aprendiendo a vencer con la experiencia que se adquiere todos los días. Su madre quiere ver a Luther Nelson libre como un pájaro de alto vuelo, porque no desea que padezca los mismos sufrimientos que han tenido su familia y su gente de Barbacoas; en sus anhelos, pide que su hijo reclame el más valioso tesoro que puede tener un ser humano: la libertad; que no sea un subalterno, que tal vez sea libre físicamente, pero oprimido de pensamiento.

Más adelante, la intriga agobia los corazones de Joaquín y la familia de Yemeyá, ya que ella se dirige a la capital de Nariño para tener los resultados de la biopsia que le hicieron anteriormente: "la camioneta la espera. Yemeyá nos sonríe, se echa mil bendiciones y se pierde en la distancia"64 . Joaquín espera exasperado, sin saber qué hacer; sólo un pasaje de la música llanera de Luis Ariel Rey lo complace, en su tristeza: “Guayabo negro, nunca me digas adiós, digas adiós, que es una palabra triste. Corazones que se quieren, corazones que se quieren, nunca deben despedirse ${ }^{\mathbf{6 5}}$. Es como una premonición del esposo de Yemeyá para no despedirse de su negra, a la que tanto ama, porque el amor rompe todas las imposibilidades ante cualquier situación melancólica.

El dolor de Joaquín se vuelve cada vez más intenso y la música andina parece ser el único remedio que mitiga su vacío: "son las seis de la tarde; una hora melancólica y fría. Hago sonar la quena que llevo en la mochila; interpreto cualquier melodía taciturna; retrocedo a mis páramos. La dicha pasó vertiginosamente por

62. Estupiñán, Eclipse de luna, 88.

63. Estupiñán, Eclipse de luna, 102-103.

64. Estupiñán, Eclipse de luna, 104.

65. Estupiñán, Eclipse de luna, 104. 
Barbacoas. No sé qué ocurrirá mañana; cada día trae nuevas penas. Ejecuto mi dolor entonando Tatatí de Inti Illimani" ${ }^{66}$.

Éste es uno de los momentos en los cuales la música, que siempre ha oído e interpretado Joaquín, proclama toda su esencia y su poder catártico; para Estupiñán, fue relevante transmitir sensaciones de dolor por medio de la música andina, porque revela la situación real que vive la población latinoamericana; por ello, destaca en varios capítulos partes musicales de esta índole ya que, como lo confesó en su reportaje, la música andina y la llamada social o de protesta traen en sus mensajes la situación de la gente sencilla, de la gente pobre. Los artistas que desfilan en la novela son parte de todos los que ha admirado.

No existen rivalidades y rencores para los subalternos; la Colonia dejó una inquebrantable huella de dolor en América; los abusos fueron evidentes; sin embargo, Joaquín no guarda ese tipo de malos recuerdos; por ello, antes de marcharse de la ciudad de Pasto, los médicos del hospital les dedican unas canciones para mitigar un poco todos aquellos sufrimientos que tuvieron en la estadía durante el tratamiento de Yemeyá contra el cáncer: "Desde que te quiero, me ha cambiado todo, desde que te quiero me quedé sin alas y me hice esclavo tuyo"67, dice el tema musical titulado Desde que te quiero, del español José Luis Perales.

Estupiñán incorpora varias canciones en su novela, que le dan un toque prodigioso al contenido del aparte y a la intención comunicativa; cada melodía es un disparo exacto en el sentimiento encontrado, lo que se debe a que el autor tiene un buen gusto por la música y una gran experiencia musical andina; formó parte de la agrupación "Kamur" del municipio de Cumbal, donde era el charanguista y, por esta razón, incorpora este tipo de temas en su narrativa. Otro de los motivos fue su deseo de realizar una distinción al trabajo musical de los artistas que alegran los corazones de la gente que los escucha. En uno de los reportajes, realizado el 11 de abril de 2013, afirmó lo siguiente: "también hice homenaje a los artistas de la canción social de todos los tiempos: Horacio Guarany, Pablo Milanés, Ana y Jaime, Daniel Toro, etc., y a los grupos de música andina”.

Se aproxima el momento de la despedida final; el viaje de Yemeyá no aguarda más al lado de Joaquín y su hijo Luther Nelson; los últimos instantes de brío quiere pasarlos con ellos; mientras pasean por el jardín, Joaquín, entristecido, recuerda a Eliades Ochoa y Compay Segundo, con su canción cubana: “... rumbo al abismo, triste esperanza del que lucha tanto. Pobre de mí, oh triste sino. Soñar 
me está acabando la existencia, tú lo sabes. Qué voy a hacer si he de seguir cual peregrino. Sólo pena y dolor para mí es la vida"68.

Joaquín describe los pocos minutos de vida de su alma gemela:

Yemeyá se adormece; no responde; le digo que el día está despejado, el cielo azul. Sus párpados esconden un par de ojos claros que se apagan. Un sentido suspiro brota de sus pulmones, como lamento de su espíritu y se repite constantemente. Mil puñaladas hieren mi corazón ${ }^{69}$.

Para terminar este tema de la música en Eclipse de luna, Joaquín aún tiene fuerzas para escuchar la última composición de Daniel Toro y su Mariposa triste:

Qué camino gris te trajo, mariposa nueva, cansada de andar, qué viejo dolor callabas, bajo tus ojeras, queriendo volar. Quién te empujó hasta mis brazos, para abrir la noche de mi soledad. 0 te di la flor pensando que necesitabas volver al amor, y fue a un tiempo azul quebrado, por cuatro palabras golpeando mi voz. Quién puso hiel en tu boca, para que me dieras tan sólo un adiós. Cuando mi pueblo va quedando en sombras, cuando mi sangre sin querer te nombra, cuando el amor y el estío, juegan por el río, mi alma se me va en pedazos. Quién te arrancó de mis brazos, mariposa triste, cansada de andar.

Dónde estaba el sol la tarde que abriste las alas y echaste a volar; qué caparazón de noche te envolvió en la noche de la oscuridad. Quién te llevó calle abajo donde la vida se esconde a llorar. Pero están en mí tus ojos, como dos abrojos queriendo volver. Y a la orilla del verano, andarán mis manos, buscando tu piel. Quién te encerró en mi guitarra, pálida cigarra de mi atardecer. Cuando mi pueblo va quedando en sombras, cuando mi sombra sin querer te nombra, cuando el amor y el estío, juegan por el río, mi alma se me va en pedazos. Quién te arrancó de mis brazos, mariposa triste cansada de andar ${ }^{70}$.

En este apartado, Estupiñán transcribe la canción completa de este cantante argentino, porque quiere trascender uno de los instantes más dolorosos que Joaquín siente en su vida; la melodía rememora los momentos compartidos con Yemeyá, la persona que lo acompañó durante su efímera vida en Barbacoas; efímera, porque desde su partida, su sentido cambia; ya no es igual; sin saber que todo sería sombrío; puertas sin luz que lo dejan atrás, con su hijo y su charango, y sin su mariposa, que ya no regresará jamás. Joaquín se despide para siempre de Barbacoas, escribiendo un epitafio en el sepulcro de su gran amor: "Yemeyá,

68. Estupiñán, Eclipse de luna, 132.

69. Estupiñán, Eclipse de luna, 136.

70. Estupiñán, Eclipse de luna, 143-144. 
el amor que se volvió estrella antes de tiempo"71 , inscripción que simboliza lo que representó esta hermosa afrodescendiente en su vida.

\section{CONCLUSIONES}

La pregunta que se planteó en este trabajo investigativo, acompañada del método hermenéutico, facilitó la interpretación de la novela Eclipse de luna, que desarrolla la historia de dos personajes "subalternos": Joaquín y Yemeyá; los dos formaron un eclipse de luna por medio del amor que mantuvieron en el municipio de Barbacoas y, como fruto de su unión, surgió el único tesoro invaluable que Joaquín debió haber buscado desde un principio: su hijo Luther Nelson.

Es ineludible estudiar la vigencia de Eclipse de luna, porque sublima la riqueza etnoliteraria que presenta Nariño por medio de su contenido narrativo; un ramillete de sucesos que enmarcan la historia, la belleza musical, el amor, el dolor y la muerte. Antonio Cándido expresa que una obra no debe disociarse de la realidad social, pues ésta sólo puede entenderse al fundir texto y contexto en una interpretación dialécticamente íntegra. Por ello, la novela de Estupiñán, a través de una historia de amor y dolor en tierras nariñenses, reivindica los padecimientos que aún viven el indio y el afrodescendiente en el Departamento; de igual forma, interpretar su argumento central permite liberar la posibilidad de la unión fraternal en la multiculturalidad de las razas.

La subalternidad, que choca con muros sensibles, es un tema que intranquiliza a Ricardo Estupiñán, tesis que resalta en su novela con tono decolonial. Cabe destacar que su ideal, en el Departamento de Nariño, es buscar, a través de su propuesta narrativa, la emancipación del subalterno. El tema central de Eclipse de luna se trasforma, así, en un reclamo social para vivir dignamente en lo que el gobierno nacional ha constituido como un "Estado social de Derecho". Este autor recorrió varios municipios del Departamento y logró darse cuenta de la fría realidad que viven un campesino, un afrodescendiente, un indio, un niño, una mujer, un anciano, elementos subalternos que se retoman en su obra, para adelantar una crítica sociocultural. También, es natural afirmar que la influencia de la música andina y afroamericana lo haya inclinado hacia la trama de su novela, pues su narrativa provee un repertorio de la multiplicidad musical que existe en el continente, que suscita temas como la libertad, el amor, el dolor y la muerte.

La novela objeto de estudio no vislumbra una posición local entre Cumbal y Barbacoas; se escribe indiscutiblemente dentro del marco literario latinoame-

71. Estupiñán, Eclipse de luna, 148. 
ricano, pues rompe con los esquemas periféricos, al abordar, en su integridad estética, temas y problemáticas como la subalternidad, que extrapola cualquier territorio del continente americano. Al hablar con Estupiñán, señala que los pueblos son universales porque los sentimientos de sus gentes son idénticos, sin importar el clima, la distancia, la ubicación geográfica o los personajes, porque todos pertenecemos a la misma raza humana, a un único planeta; además, cabe señalar que el amor no tiene color. Por eso la literatura también es universal.

En esta medida, la narrativa de Eclipse de luna es una posibilidad más para viabilizar relaciones sociales en Nariño, al reforzar la conciencia sobre algunos de los valores culturales que ya no se promueven ni cultivan; fortalece, por medio de su argumento, la solidaridad de las presencias raciales con el propósito de preservar la solidaridad y la exaltación de las tradiciones. Es un trabajo importante y necesario dentro del estudio de la crítica literaria en Colombia, pero no el último, que puede llegar a descubrir la grandeza de su intención comunicativa, porque pueden existir múltiples interpretaciones polifónicas.

En términos generales, esta investigación contribuye al desarrollo del proceso crítico literario en Nariño, porque es una posibilidad más para que los escritores, como Ricardo Estupiñán, se conociesen a nivel nacional e internacional. El autor de Eclipse de luna menciona que la crítica literaria es indispensable, puesto que "todo lo que se diga de los escritores es importante, bueno o malo, porque mantiene viva la literatura". Además, para que obras como éstas, se lean, estudien y revaloren por sus valiosos aportes socioculturales. La tarea de la crítica, en la actualidad, ya no es sólo literaria, sino también cultural; no se limita a escudriñar un contenido textual; ahora quiebra posturas coloniales de un medio social, al resaltar el género, las razas y las clases minoritarias. 


\section{REFERENCIAS BIBLIOGRÁFICAS}

Bajtín, Mijaíl. Teoría y estética de la novela. Madrid: Editorial Taurus, 1989.

. Problemas de la poética de Dostoievski. México: Fondo de Cultura Económica, 1986.

Cándido, Antonio Literatura y sociedad. México: Centro Coordinador y Difusor de Estudios latinoamericanos de la Universidad Nacional Autónoma de México, 2007.

Castro, Santiago y Eduardo Mendieta (eds.). Teorías sin disciplina, latinoamericanismo, poscolonialidad y globalización en debate. México: Miguel Ángel Porrúa, 1998.

Cornejo, José. La formación de la tradición literaria en el Perú. Lima: Centro de estudios y publicaciones, 1989.

De Andrade, Oswald. Oswald de Andrade: obra escogida. Caracas: Biblioteca de Ayacucho, 1981.

Dussel, Enrique. "Filosofía Política en América Latina Hoy". Seminario de Doctorado en Estudios Culturales Latinoamericanos de la Universidad Andina Simón Bolívar (2013), https://www.youtube. com/ watch?v=1J20_uSICpE (miércoles 13 de noviembre de 2013).

Estupiñán, Ricardo. Eclipse de luna. Pasto: Edinar, 2011.

. Caminando por el Sur, historias y leyendas de Nariño. Pasto: Edinar, 2003.

Fanon, Franz. Los condenados de la tierra. Trad. Julieta Campos. México: Fondo de Cultura Económica, 1963.

Fernández, Roberto. Para una teoría de la literatura hispanoamericana. Bogotá: Instituto Caro y Cuervo, 1995.

Friedemann, Nina de. La saga del negro. Bogotá: Universidad Javeriana, 1997.

Guerra, Gonzalo. Tierra del oro: Reseña histórica de Barbacoas. Pasto: Imprenta Departamental, 1980.

Guerrero, Gerardo. Estudios sobre el municipio de Cumbal. Bogotá: Internacional de Impresos El Dorado, 1998.

Guha, Ranajit. Las voces de la historia y otros estudios subalternos. Barcelona: Crítica, 2002.

Jauss, Hans. Experiencia estética y hermenéutica literaria. Madrid: Taurus, 1986.

Mignolo, Walter. Espacios geográficos y localizaciones epistemológicas: la ratio entre la localización geográfica y la subalternización de conocimientos (2000), http://www.javeriana.edu.co/ pensar/ Rev34.html.

Moraña, Mabel. Estudios culturales, acción intelectual y recuperación de lo político. En: Revista Iberoamericana, Vol. LXIX, No. 203 (ab.-jun., 2003): 425-430, http://revista-iberoamericana. pitt.edu/ojs/index.php/ Iberoamericana/article/viewFile/5668/5815.

. El Boom del Subalterno. En: Castro-Gómez, Santiago y Eduardo Mendieta (eds.) Teorías sin disciplina latinoamericanismo, poscolonialidad y globalización en debate. México: Porrúa, (1998), http:// www.ceapedi.com.ar/imagenes/biblioteca/libros/148.pdf

República de Colombia. Constitución Política de Colombia de 1991. Bogotá: Base de datos políticos de las Américas, 2002.

Restrepo, Eduardo y Axel Rojas. Inflexión decolonial: fuentes, conceptosy cuestionamientos. Popayán: Editorial Universidad del Cauca, 2010, http://www.ram-wan.net/restrepo/ documentos/Inflexion.pdf

Rincón, Carlos. El cambio en la noción de literatura. Bogotá: Instituto Colombiano de Cultura, 1978. 